Article

\title{
Significant Life Events and Career Sustainability: A Three-Wave Study
}

\author{
Shagini Udayar ${ }^{1, *(\mathbb{D})}$, Leandro Ivan Canzio ${ }^{2}$, Ieva Urbanaviciute ${ }^{2}\left(\mathbb{C}\right.$, Jonas Masdonati ${ }^{1,2}\left(\mathbb{C}\right.$ and Jérôme Rossier ${ }^{1,2} \mathbb{(}$ \\ 1 Institute of Psychology, University of Lausanne, CH-1015 Lausanne, Switzerland; \\ Jonas.Masdonati@unil.ch (J.M.); jerome.rossier@unil.ch (J.R.) \\ 2 Swiss National Centre of Competence in Research LIVES, University of Lausanne, \\ CH-1015 Lausanne, Switzerland; leandroivan.canzio@unil.ch (L.I.C.); ieva.urbanaviciute@unil.ch (I.U.) \\ * Correspondence: shagini.udayar@unil.ch
}

Citation: Udayar, S.; Canzio, L.I.; Urbanaviciute, I.; Masdonati, J.;

Rossier, J. Significant Life Events and Career Sustainability: A Three-Wave Study. Sustainability 2021, 13, 13129. https: / / doi.org/10.3390/ su132313129

Academic Editors: Caterina Gozzoli and Diletta Gazzaroli

Received: 28 October 2021

Accepted: 20 November 2021

Published: 26 November 2021

Publisher's Note: MDPI stays neutral with regard to jurisdictional claims in published maps and institutional affiliations.

Copyright: (c) 2021 by the authors. Licensee MDPI, Basel, Switzerland. This article is an open access article distributed under the terms and conditions of the Creative Commons Attribution (CC BY) license (https:/ / creativecommons.org/licenses/by/ $4.0 /)$.

\begin{abstract}
Over the last three decades, the professional landscape has changed, and career paths have become more plural, complex, and flexible, as well as less predictable. Consequently, career sustainability has become a major concern. Since the framework of sustainable careers captures the complexities of modern careers, we used it in the present study to understand how various types of significant life events (i.e., negative work events, negative nonwork events, positive work events, and positive nonwork events) hinder or foster career sustainability among 870 professionally active adults in Switzerland using a longitudinal design. We used repeated measures analysis of variance to study changes in health (i.e., self-rated health and stress at work), happiness (i.e., life satisfaction, quality of life, and job satisfaction), and productivity (i.e., employability and career prospects) by the type of significant life events over time, from 1 year before the event (T0) to 1 year after the event (T2). Results indicated that work events are important to consider when studying career sustainability as there is evidence for spillover effects from work to life. Specifically, experiencing positive work events seems to foster career sustainability, and these effects seem to be stronger than the negative effect of negative work or nonwork life events on health, happiness, and productivity.
\end{abstract}

Keywords: career sustainability; significant life events; self-rated health; life satisfaction; quality of life; work stress; job satisfaction; employability; career prospects

\section{Introduction}

Nowadays, career paths have become more flexible and less linear, and they are characterized by multiple transitions [1]. Due to these complexities, new career theories and models, such as protean careers [2], boundaryless careers [3], kaleidoscope careers [4], and life design [1], have underlined the importance of individual agency in constructing careers while also taking into account some contextual factors. Hence, numerous studies have highlighted the role of personal resources and individuals' responsibility in constructing their career. However, life events, which are often intrinsically related to the context and take place sometimes out of one's control, also play an important role in shaping career paths. Indeed, common major life events, such as childbirth, the death of a loved one, a promotion, or unemployment, have an impact on almost all aspects of daily life, including work [5-7]. Some of these events may significantly influence career development and probably affect one's career sustainability.

Career sustainability refers to "sequences of career experiences reflected through a variety of patterns of continuity over time, thereby crossing several social spaces, characterized by individual agency, herewith providing meaning to the individual" [8] (p. 7). To understand what makes a career sustainable, De Vos and colleagues [9] proposed a theoretical framework highlighting three critical interacting dimensions of sustainable careers (i.e., the person, the context, and the time) and three core indicators of a sustainable 
career (i.e., health, happiness, and productivity). The interplay between these dimensions and indicators is central in analyzing the underlying processes of career sustainability.

The present study aims to advance research on sustainable careers by taking a contextualized approach to careers and by investigating how various types of life events hinder or foster career sustainability. Therefore, this study, based on the career sustainability framework [9], will contribute to the general understanding of how events in various life contexts interact with time to impact a person's health, happiness, and productivity.

\section{Conceptualizing Major Life Events}

Life events have been conceptualized using various perspectives, each of them stressing some of their characteristics, and their consequences on individuals and their careers. Thus, the life course approach addresses life events in terms of ruptures, bifurcations, or turning points, which trigger changes and from which a range of possible paths can be followed [10-12]. This perspective also stresses the role of agency. Combining the event and personal agency gives a continuum between forced or involuntary and chosen or voluntary events [13]. In health psychology, life events have mainly been studied within a stress perspective that considers them as a specific type of stressor disturbing the daily routine and leading to a number of predominantly negative outcomes $[14,15]$. The stress triggered by an event could depend on its feature (e.g., perceived intensity, duration, predictability, and controllability of the event). In vocational psychology and career counseling, researchers have mainly studied life events as triggers of transitions [16]. For example, Schlossberg's transition framework [17] considers life events as complex transitions during which individuals experience challenges. In his model, expectancy and occurrence interact to define different types of transitions. More recently, Akkermans and colleagues [18] conceptualized career shocks as rare events that are often not under one's control and trigger a deliberate thought process about one's career. These shocks can happen at any time over the life course, vary in terms of valence, foreseeability, frequency, duration, intensity, and locus, and lead to career transitions. In work and organizational psychology, Morgeson and colleagues [19] proposed a general theory of how events may affect organizations, namely event system theory (EST). According to EST, events are discrete and discontinuous happenings (having an identifiable temporal beginning and end and occurring in a specific context) involving the intersection of various entities. An event is characterized by three components in interaction: the event strength, space, and time. By describing these three components, EST shows how spatial and temporal characteristics of an event interplay with its strength to trigger impactful changes. Finally, Luhmann and colleagues [20], highlighting the lack of a conceptual framework in psychology that suggests a systematic examination of the effects of major life events on psychological outcomes, recently developed a dimensional taxonomy of nine perceived characteristics of major life events: five event-focused characteristics (i.e., valence, predictability, challenge, external control, and extraordinariness) and four consequence-focused characteristics (i.e., impact, change in world views, social status changes, and emotional significance).

Although each perspective has identified a number of event characteristics, the present paper focuses on three of its characteristics that seem capital for most of these perspectives: their valence, emotional significance, and domain.

\subsection{Valence, Emotional Significance, and Domain of Life Events}

By valence, we refer to the emotional experience of events, which has been to date mostly assessed through individuals' appraisal of the event as positive or negative. One issue with subjective appraisal is that the reported valence often corresponds to the valence associated with the consequences of experienced events and not the event itself. Moreover, although subjective ratings may help in linking reported events and subsequent states of health and well-being (because these reports can better reflect the actual experiences of the respondents), they are difficult to assess in panel surveys where open-ended questions are used to assess life events. In any case, the event valence showed promising results 
when studying well-being. For example, event valence has been proven to explain more variability in subjective well-being (SWB) than other event characteristics [20].

By emotional significance, we refer to events that bear on the person's interests or concerns. Indeed, not all life events are equally important to individuals and are relevant to their health and well-being. According to cognitive appraisal theory [21], an event will have consequences on the person not simply because it occurs but because it has an emotional significance for them. From a methodological point of view, this translates into surveys asking respondents to report only events that were significant for them rather than collecting data on all trivial or ordinary life events using checklists [22,23]. One study recently highlighted the very high rank-order stability and intraclass correlations, as well as the nonsignificant mean-level change of the emotional significance of major life events [24].

Finally, the domain or the life sphere where the event occurs is also important to consider, especially for examining work-life spillover effects [25]. For example, studies have shown that stressful life events in private life negatively impacted well-being at work by impeding the adequate use of psychological resources at work [26,27].

\subsection{Life Events and Career Sustainability}

A career is considered sustainable when, despite having faced adverse life events or disruptions, people experience continuity and meaning in their career paths, thus maintaining their health, happiness, and productivity in both the short and long run. Whereas health refers to the fit of the career with one's physical and mental capacities, happiness refers mainly to how happy and satisfied individuals are with their careers. Productivity refers to the individuals' actual level of performance and their employability or career potential in the future [9]. Thus, productivity includes both work and career performance.

Recent research based on this framework has mainly focused on the importance of individual or contextual factors related to career management in promoting career sustainability [28]. Most studies have focused on agency, competencies, and psychological resources $[29,30]$. The context has been mostly studied by taking into account organizational factors [31,32], employer-related contextual aspects [33], or working conditions [34].

Even though the career sustainability framework is not presented as an event-oriented theory, life events and changes might play an important role in it. Indeed, during the course of their life, individuals are likely to experience several life events that positively or negatively impact their career, and they may have to activate resources to cope with them. A few studies have investigated the role of events by examining the relation between career shocks (i.e., unexpected career events) and career sustainability [35,36]. To our knowledge, however, no study has investigated the role of a broad spectrum of life events on all three indicators of career sustainability.

\section{Life Events in Relation to Health, Happiness, and Productivity \\ 3.1. Life Events and Health}

As the career sustainability framework considers individuals embedded in various life domains, both general and work-related indicators of health and well-being should be considered in relation to life events. Among the indicators of general health, general mental and physical health have been largely studied in relation to life events. A group of studies have analyzed the impact of life events on health using the stress perspective. In general, findings have suggested that individuals who have experienced more stressful major or minor events also tend to have poorer mental health [37-39]. However, most of the studies have been conducted on children, adolescents, or clinical adults and have focused on the frequency of the events without taking into account other characteristics such as emotional significance or domain. Moreover, the effects of positive life events have received less research compared to those of negative events. Although a few studies have shown evidence that favorable events can enhance health [40,41], others have pointed out their disruptive effect on health, which was explained by individual differences [42]. 
Furthermore, researchers have studied the relation between life events and health at work through the lens of stress and burnout. Daily experiences of violence at the workplace have been shown to lead to burnout [43], whereas positive work events have been shown to be negatively related to work stress [44]. Based on a literature review, Hakanen and Bakker [27] concluded that positive nonwork events, such as marriage or giving birth, do not seem to be associated with job burnout, whereas negative nonwork events may be.

\subsection{Life Events and Happiness}

Among the indicators of overall happiness, SWB [45] and, in particular, life satisfaction have received the most research in relation to life events [6]. A set of studies have analyzed the effect of major life events on SWB using a life course perspective. Although early studies have shown that life events are only moderately associated with changes in SWB and that this lasts only for a short period [46], recent research has suggested that some life events may be associated with marked long-lasting changes in SWB [47,48]. Some studies have mainly focused on the valence of the events and how it impacts SWB [49,50]. For example, Gomez and colleagues [49] found that negative life events had a stronger impact on SWB compared to positive life events. A meta-analysis [6] showed that events had various effects on cognitive (e.g., life satisfaction) and affective (e.g., depressed mood) SWB depending on the domain of the event (e.g., family or work) and the time since its occurrence (short- vs. long-term consequences): while unemployment had a negative strong effect on cognitive SWB, followed by an increase over time (the pre-event level of cognitive SWB was reached again 3 years after the event), childbirth had a positive initial effect on cognitive SWB, followed by a quick decrease, although its effect on affective SWB was initially negative, followed by an increase in the long run. Surprisingly, the valence of the event (e.g., positive, neutral, and negative) did not moderate the effect of the event on SWB. Luhmann and colleagues [20] recently conducted several studies to examine the relation between perceived event characteristics and life satisfaction. They observed that the event characteristic that had the highest predictive power was the perceived valence of major life events. Experiencing a negative event was associated with an immediate decrease in life satisfaction followed by a more pronounced increase in life satisfaction across time. In contrast, experiencing a positive event was associated with an immediate increase in life satisfaction, followed by a less pronounced increase across time.

Another indicator of overall happiness is quality of life $(\mathrm{QoL})$, a construct that includes both objective (objective health and life conditions) and subjective components (satisfaction with various life domains). Pocnet and colleagues [51] examined the relation between major life events and QoL within a nonclinical general adult population. This study highlighted the negative association between critical events and QoL. This relation was equally strong, whether the critical events had happened recently or some years ago. Similar results have been found in a few studies investigating specific work-related events such as job loss and unemployment and their relation to QoL [52,53]. To date, no studies to our knowledge have examined the relation between positive major life or work events and QoL. However, based on health and life satisfaction studies, we may expect positive life events to have positive consequences on QoL.

Although most of the studies on major life events have focused on overall SWB, a few have investigated work-related well-being such as job satisfaction. The latter refers to the way employees feel and think about their job [54]. Research has shown that major life events, such as the birth of the first child, had a long-lasting spillover effect on job satisfaction when compared to marriage [55]. Violence at the workplace has also been shown to have a detrimental effect on job satisfaction [43]. In the same way, organizational events and personal work events, whether positive or negative, seem to predict job satisfaction [56]. In sum, except for the studies focusing on specific events, the link between life events and job satisfaction using a longitudinal and global perspective has not been studied to date to our knowledge. 


\subsection{Life Events and Productivity}

According to De Vos and colleagues [9], performance in one's current job, as well as employability and career prospects, which are essential for long-term performance, could be considered as indicators of one's level of productivity. Perceived employability is defined as individuals' perceptions of their opportunities in the labor market [57]. Only little research has been done to investigate the effect of major life events on productivity through their effect on perceived employability. For example, Blokker and colleagues [35] found that both positive and negative career shocks moderated the relationships between career competencies and perceived external employability (i.e., employment opportunities on the external labor market). Concerning career prospects, which refer to individuals' perception of their career progression possibilities in the future [58], no study to our knowledge has investigated their relation with life events. However, we could assume that life events are associated with career prospects in a similar way as with job satisfaction, work stress, and employability.

\section{The Present Study}

The aim of the present study was to investigate the extent to which various types of life events hinder or foster career sustainability, based on the above-mentioned career sustainability framework [9]. To do so, we first assessed significant life events using objective ratings of the most salient characteristic of events, that is the valence, by distinguishing between positive and negative events. Given that work domain is central to our framework and is in interaction with other life domains, we also distinguished between work and nonwork events. In sum, by considering emotionally significant life events and combining the valence and domain, we distinguished between four types of life events: significant positive work events, significant negative work events, significant positive nonwork events, and significant negative nonwork events. Second, health, happiness, and productivity indicators were considered altogether and within a longitudinal perspective of career sustainability. We then assessed their levels 1 year before the event (T0), on the year of the event (T1), and 1 year after the event (T2). We examined the relation between life events and work stress, job satisfaction, perceived employability, and career prospects (considered as indicators of work-related health, work-related happiness, and productivity, respectively). In parallel, we analyzed the relation between life events and self-related health (SRH), life satisfaction, and QoL (considered as indicators of overall health and happiness, respectively).

Since work occupies a central place in one's life and work events are assumed to have short and long-term consequences on all three indicators of career sustainability [9], we expected significant work events to have immediate and long-lasting effects on productivity, work-related well-being, and the overall indicators of health and happiness.

Hypothesis 1. Negative work events will hinder career sustainability, whereas positive work events will foster career sustainability. Therefore, we expected that individuals who experienced negative work events at $\mathrm{T} 1$ would report lower levels of health, happiness, and productivity as compared to T0, with this negative effect remaining 1 year later at T2. Individuals who experienced positive work events at $T 1$ would report increased levels of health, happiness, and productivity as compared to $\mathrm{T} 0$, with this positive effect remaining 1 year later at $\mathrm{T} 2$.

Similarly, because the career sustainability framework stresses the importance of taking into account individuals' experiences in different life spheres and therefore the existence of spillover effects, we also expected that nonwork life events would have effects on productivity, work-related well-being, and the overall indicators of health and happiness.

Hypothesis 2. Negative nonwork life events will hinder career sustainability, whereas positive nonwork life events will foster career sustainability. Therefore, we expected that individuals who experienced negative nonwork events at $\mathrm{T} 1$ would report decreased levels of health, happiness, and 
productivity as compared to $T 0$, with this negative effect remaining 1 year later at $T 2$. Individuals who experienced positive nonwork events at $T 1$ would report increased levels of health, happiness, and productivity as compared to T0, with this positive effect remaining 1 year later at $\mathrm{T} 2$.

Given that the events happening at work should be more closely related to how individuals feel and think about this context than the events happening in other life domains, we expected the effect of significant work events to be stronger than the effects of significant nonwork events on work-related indicators.

Hypothesis 3. Negative and positive work events will have stronger effects on work-related indicators than negative and positive nonwork events.

The effect of significant life events on career sustainability were examined beyond the effect of age, gender, income, and personality traits, which are all well-known correlates of health and well-being [59-61]. The effect of daily hassles was also controlled given the importance of distinguishing between major and minor life events.

\section{Method}

\subsection{Participants}

We conducted the analyses on a roughly representative sample of the French- and German-speaking Swiss working population $(N=870)$. We drew the data from Waves 5(T0), 6 (T1), and 7 (T2) of a 7-year longitudinal survey on professional paths conducted each year from 2012 to 2018 at the Swiss National Center of Competence in Research-Overcoming Vulnerabilities: Life Course Perspectives (LIVES). The survey assessed participants' professional situation and some sociodemographic variables, the perception of their work and social environment, and some of their psychological characteristics and resources. A complete description of the research and collected data are stored in the FORSbase data repository and are available upon request (https: / / forsbase.unil.ch/project/study-publicoverview /16093/0/, accessed on 23 November 2021).

We used the data of 870 participants who fully completed the survey in the three consecutive last waves (W5-W7). They were aged between 31 and 61 at W6 (i.e., T1 of the current study), and $50.9 \%$ of the sample were female, with a mean age at W6 $=47.76$, $S D=8.10$. The participants were all employed at W5 (T0), although their employment status could have changed in the successive waves. Specifically, 836 participants were employed, 20 were unemployed, and 14 were nonactive at W6. Also, 821 were employed, 32 were unemployed, and 17 were nonactive at W7.

We conducted dropout analysis and compared the retained sample to employees who participated at W5 but dropped out from the study in the next waves $(N=356)$. These analyses revealed no differences in terms of gender, age, personality traits, life satisfaction, self-rated health, and perceived quality of life. The only exception was for household income: Employees in the dropout sample reported a lower household income at W5 compared to employees in the retained sample $[\Delta M=0.50, t(1134)=3.54, p<0.001$, $d=0.25]$.

\subsection{Procedure}

At the beginning of each year, participants of the Professional Paths survey received a letter explaining the aim of the study and inviting them to participate to the study, which was voluntary. Confidentiality was ensured as data were collected anonymously using a 6-digit personal code associated to each participant. The entire process complied with the ethical standards of the Swiss Society for Psychology. 


\subsection{Measures}

\subsubsection{Significant Life Events}

The respondents were asked to indicate whether they had experienced any significant life events over the course of a year preceding W6. If so, they had to describe the events they experienced using an open text format. Two raters (first and second authors of the current paper) coded the responses into various categories. To do this, all five authors first created and validated a codebook. We applied a theory-based approach to the creation of the codebook, following the three-step procedure by Boyatzis [62]:

1. generating the code;

2. reviewing and revising the code in context of the data; and

3. determining the reliability of coders and the code.

The following categories were generated based on the life events literature (see Introduction section): valence, predictability, frequency, and domain of the event. To set the inclusion criteria, existing life event lists have been considered: the Stralsund Life Event List [23], the revised 51-event Social Readjustment Rating Scale [22], the affective work events taxonomy [63], and the PERI Life Events Scale [64].

After starting to code the events, it became evident that the participants did not provide information about event predictability. For this reason, the raters did not code this category and only coded the number of events reported, and for each event, they estimated its valence (i.e., positive, negative, mixed, neutral, impossible to determine), domain (i.e., work, family, health, education, leisure, and other), and frequency (once in the past year or more than once).

Finally, Kappa Interrater reliability was calculated for the two categories of interest in this study: overall valence of all the reported events together (i.e., work and nonwork events) and valence of reported work events. Kappa Interrater reliability was $\mathrm{K}=0.82$ (strong agreement) for overall valence and $\kappa=0.68$ (moderate agreement) for work valence [65]. The two raters went through all of the mismatched cases until an agreement was found.

By combining these two categories, four types of events were distinguished: positive work events, positive nonwork events, negative work events, and negative nonwork events. We also added a fifth type (i.e., no events reported), which we used as a baseline in our analysis. We recoded mixed valence events $(n=43)$, neutral valence events $(n=38)$, events to which it was impossible to attribute a valence $(n=16)$, and skipped responses $(n=4)$ into missing values.

\subsubsection{General Health and Happiness Indicators}

Self-Rated Health (SRH). We measured SRH at W5, W6, and W7 using one item developed and used by the World Health Organization [66]. We asked the participants to evaluate their general health using a 5-point Likert-type scale $(1=$ very bad, $5=$ very good $)$.

Life Satisfaction (SWLS). We used the 5-item Satisfaction With Life Scale [67] to assess the global cognitive judgments of satisfaction with one's life at W5, W6, and W7. The participants were asked to rate their life satisfaction on a 7-point Likert-type scale $(1=$ strongly disagree, $7=$ strongly agree $)$. Cronbach's alpha coefficients were $0.90,0.91$, and 0.92 for W5, W6, and W7, respectively.

Quality of Life (QoL). We measured QoL using a one-item scale at W5, W6, and W7. This item is similar to what can be found in other international surveys and was adapted to the Professional Paths study. The participants were asked to rate their overall QoL on a 5-point Likert-type scale $(1=$ very bad, $5=$ very good $)$.

\subsubsection{Workplace Health, Happiness, and Productivity Indicators}

Work Stress (GWSS). We used the 9-item General Work Stress Scale [68] at W5, W6, and W7 to measure the work-related level of stress. This questionnaire uses a 5-point Likert-type scale $(1=$ never, $5=$ always $)$. The respective Cronbach's alpha coefficients were 0.90, 0.91, and 0.91 for W5, W6, and W7. 
Job Satisfaction (JOBSAT). We used the 5-item JobSat inventory [69] at W5, W6, and W7 to measure the satisfaction with various job facets (i.e., general working conditions, salary, job security, and quality of the relationships with the supervisor and colleagues). The participants were asked to rate their job satisfaction on a 4-point Likert-type scale ( $1=$ not at all satisfied, $4=$ highly satisfied $)$. The Cronbach's alpha coefficients were $0.71,0.72$, and 0.72 for W5, W6, and W7, respectively.

Employability. We measured perceived employability using a one-item scale at W5, W6, and W7. Participants were asked to indicate their perceived difficulty in finding a similar job to the one they had at the time using a 4-point Likert-type scale $(1=$ very difficult, $4=$ very easy). Previous studies have successfully applied similar single-item measures to evaluate perceived employability [70].

Career Prospects. We measured career prospects with a one-item scale at W5, W6, and W7. The respondents were asked to indicate their agreement with the item "My career prospects and promotion opportunities are good" using a 4-point Likert-type scale (1 = strongly disagree, 4 = strongly agree $)$.

\subsubsection{Control Variables}

We used age, gender, and household income from W6 as control variables. While gender was coded as $1=$ male and 2 =female, household income, which referred to the annual income of the household, was used as a continuous variable $(1=$ lowest annual income, 8 = highest annual income).

\subsubsection{Personality Traits}

We used the 60-item NEO Five-Factor Inventory-Revised [71] to measure three out of the five main personality dimensions proposed by the Five Factor Model: neuroticism $(\mathrm{N})$, extraversion $(\mathrm{E})$, and conscientiousness (C). Contrary to all of the other variables, personality traits were assessed in Wave 4 . Each subscale contained 12 items, and the participants had to rate their personality traits on a 5-point Likert-type scale ( 1 strongly disagree, 5 = strongly agree). The Cronbach's alpha coefficients for the three dimensions were $0.86,0.74$, and 0.72 , respectively.

\subsubsection{Daily Hassles}

We assessed daily hassles (DH) at W6 using the 18-item LIVES-DHS [72] that taps into the five sources of DH: financial, physical, relational, environmental, and professional. Participants had to indicate to what extent they worried about a number of sources of preoccupations on a given day on a 4 -point Likert-type scale $(1=$ not at all, $4=$ very much). Two work-related were given only to employed participants. The Cronbach's alpha coefficient for the total score was 0.95 .

\subsection{Statistical Analysis}

The data were analyzed using SPSS. First, bivariate correlations were calculated to assess the pattern of relationships between the study variables. Then, normality checks were carried out on the residuals using skewness and kurtosis analyses. As we used a sample larger than 300 participants, either an absolute skew value larger than 2 or an absolute kurtosis larger than 7 was used as a reference value for determining nonnormality [73]. To test the hypotheses, seven repeated measures analysis of variance (RM ANOVAs) were used to study changes in participants' health, happiness, and productivity by the type of significant life event over time. In this regard, time was specified as a three-level (within-subject) factor: T0 (pre-event), T1 (event), and T2 (post-event). This design was used because the major life events research has widely acknowledged that studies should use a longitudinal design in which the outcome variables are measured after the occurrence of major life events and, ideally, before they happened [20].

For each RM ANOVA, the type of significant life event (between-subject) and the following control variables were added: age, gender, neuroticism, extraversion, consci- 
entiousness, household income, and DH. Moderation analyses were conducted to test whether mean-level changes of our dependent variables across the three waves varied by the type of significant life event reported at T1. When Mauchly's test showed that the assumption of sphericity had been violated, degrees of freedom were corrected using Greenhouse-Geisser estimates of sphericity. Significant main effects and interactions (e.g., Time X Type of event) were followed up with using Bonferroni pairwise comparisons, and effect sizes were calculated: partial eta squared $\left(\eta_{p}{ }^{2}\right)$ values of $0.14,0.06$, and 0.01 were considered large, medium, and small effect sizes, respectively.

\section{Results}

\subsection{Some Examples of Significant Life Events}

Forty-seven participants reported positive work events such as events related to working conditions (e.g., more flexibility, possibility to reduce working hours, less mobbing), increases in salary, promotions, success in projects, reemployment, and job changes for better jobs. Positive nonwork events were reported by 117 participants and included family events, such as their own and/or other family members' marriage, births, their own or other family members 'physical and mental health improvement, school and/or work achievement of children, success in leisure activities, holiday trips, moving to a better location, and buying a property.

Fifty-five participants reported negative work events such as poor working conditions (e.g., conflicts with colleagues and managers, mobbing), job loss/unemployment, and burnout. Negative nonwork events were reported by 115 participants and included family events such as the death of a loved one, conflicts or separation/divorce, their own or others' physical and mental health issues, and some financial issues.

\subsection{Descriptive Analysis, and Correlations}

Table 1 presents the means, standard deviations, and bivariate correlations. Overall, each type of significant life event was significantly correlated with at least one indicator of health, happiness, and productivity, except for positive nonwork events, which were not correlated with either employability or career prospects in any of the waves. These correlations were rather small. Positive work events showed the highest correlations with GWSS at T0, JOBSAT at T1, and career prospects at T1. Positive nonwork events showed the highest correlations with SRH, SWLS, and QoL at T1. Negative work events showed the highest correlations with JOBSAT and SWLS at T1. Negative nonwork events showed the highest correlation with SRH at T1. It is interesting to note that negative work events showed a significant and small correlation with $\mathrm{DH}$.

Also, the control variables were significantly correlated with at least one indicator of health, happiness, and productivity, except for gender, which was not correlated with health indicators in all three waves.

\subsection{Effect of Type of Event on Health}

Normality checks were first carried out on the residuals, which were all normally distributed. GWSS (indicating work-related health) and SRH (indicating overall health) were used as dependent variables in the RM ANOVAs.

For perceived stress at work, results indicated a nonsignificant mean-level change in perceived work stress between T0 and T2 (see Table 2). The moderation analysis indicated a marginally significant interaction effect between the time and type of event. The interaction effect, although marginally significant, showed a significant quadratic effect, $F(4,665)=2.57, p=0.037$. We found also a main effect of the type of event. All interaction effects are represented in Figure 1. As illustrated in Figure 1a, only facing positive significant work events seems to have a positive effect on perceived stress at work but only on a short-term basis. Negative work or nonwork events were not found to increase the level of perceived stress at work. 
Table 1. Means, Standard Deviations, and Pearson Correlations $(\mathrm{N}=870)$.

\begin{tabular}{|c|c|c|c|c|c|c|c|c|c|c|c|c|c|c|c|c|}
\hline & $\mathbf{N}$ & $\mathbf{M}$ & $S D$ & 1 & 2 & 3 & 4 & 5 & 6 & 7 & 8 & 9 & 10 & 11 & 12 & 13 \\
\hline 1. Age & 862 & 47.76 & 8.10 & 1 & & & & & & & & & & & & \\
\hline 2. Gender & 870 & 1.51 & 0.50 & 0.01 & 11 ** & & & & & & & & & & & \\
\hline $\begin{array}{l}\text { 3. Household income } \\
\text { 4. Neuroticism }\end{array}$ & $\begin{array}{l}866 \\
836\end{array}$ & $\begin{array}{l}5.17 \\
2.52\end{array}$ & 2.05 & $\begin{array}{r}0.05 \\
-0.10 * *\end{array}$ & $-0.11^{* * *}$ & $\begin{aligned} 1 & \\
-0.24 * * & \end{aligned}$ & 1 & & & & & & & & & \\
\hline 5. Extraversion & 836 & 3.33 & 0.46 & -0.07 & 0.06 & $0.17 * * *$ & $-0.39 * * *$ & 1 & & & & & & & & \\
\hline 6. Conscientiousness & 836 & 3.86 & 0.43 & 0.00 & 0.03 & $0.08^{*}$ & $-0.37 * * *$ & $0.29^{* * *}$ & 1 & & & & & & & \\
\hline 7. Daily hassles & 870 & 1.64 & 0.64 & $0.06 *$ & $0.08^{*}$ & $-0.27 * * *$ & $0.35 * * * *$ & -0.05 & -0.06 & 1 & & & & & & \\
\hline $\begin{array}{l}\text { 8. SRH at T0 } \\
\text { 9. SRH at T1 }\end{array}$ & $\begin{array}{l}868 \\
870\end{array}$ & $\begin{array}{l}4.14 \\
4.17\end{array}$ & $\begin{array}{l}0.71 \\
0.77\end{array}$ & $\begin{array}{l}-0.08^{*} \\
-0.10^{* *}\end{array}$ & $\begin{array}{l}-0.04 \\
-0.01\end{array}$ & $\begin{array}{l}0.18 * * * \\
0.16 * *\end{array}$ & $\begin{array}{l}-0.37 * * * \\
-0.34 * *\end{array}$ & $\begin{array}{l}0.18^{* * *} \\
0.22^{* * *}\end{array}$ & $\begin{array}{l}0.16^{* * *} \\
0.13^{* * *}\end{array}$ & $\begin{array}{l}-0.27 * * * \\
-0.29 * *\end{array}$ & $1^{1} 3_{* * * *}$ & & & & & \\
\hline 10. SRH at T2 & $\begin{array}{l}870 \\
870\end{array}$ & $\begin{array}{l}4.17 \\
4.10\end{array}$ & 0.73 & $\begin{array}{l}-0.10 * * \\
-0.09 * *\end{array}$ & $\begin{array}{l}-0.01 \\
0.00\end{array}$ & $\begin{array}{l}0.16 * * * \\
0.14 * *\end{array}$ & $\begin{array}{l}-0.34 * * * 4 \\
-0.35 * *\end{array}$ & $0.21 * * *$ & $0.09 *$ & $\begin{array}{l}-0.29 * * * \\
-0.30 * *\end{array}$ & $\begin{array}{l}0.63 * * * \\
0.63 * *\end{array}$ & $0.67^{* * *}$ & 1 & & & \\
\hline 11. GWSS at T0 & 869 & 1.90 & 0.63 & -0.01 & -0.04 & -0.01 & $0.46^{* * *}$ & $-0.16 * * *$ & $-0.21 * * *$ & $0.25^{* * * *}$ & $-0.32 * * *$ & $-0.30 * * *$ & $-0.26^{* * *}$ & 1 & & \\
\hline 12. GWSS at T1 & 836 & 1.90 & 0.65 & -0.03 & -0.01 & 0.01 & $0.44^{* * *}$ & $-0.16 * * *$ & $-0.19 * * *$ & $0.28 * * *$ & $-0.29 * * * *$ & $-0.35 * * * *$ & $-0.33 * * * *$ & $0.69 * * *$ & 1 ( & \\
\hline $\begin{array}{l}\text { 13. GWSS at T2 } \\
\text { 14. SWLS at T0 }\end{array}$ & $\begin{array}{l}821 \\
869\end{array}$ & $\begin{array}{l}1.90 \\
5.30\end{array}$ & $\begin{array}{l}0.65 \\
1.10\end{array}$ & $\begin{array}{c}-0.06 \\
0.03\end{array}$ & $\begin{array}{l}0.01 \\
0.04\end{array}$ & $\begin{array}{l}0.03 \\
0.33^{* * *}\end{array}$ & $\begin{array}{l}0.422^{* * * *} \\
-0.49 * *\end{array}$ & $\begin{array}{l}-0.133^{* * * * *} \\
0 * *\end{array}$ & $\begin{array}{l}-0.18^{* * * *} \\
0.24^{*}\end{array}$ & $\begin{array}{l}0.26^{* * 7 *} \\
-0.35 * *\end{array}$ & $\begin{array}{l}-0.28^{* * * *} \\
0.42^{* * *}\end{array}$ & $\begin{array}{l}-0.288^{* * * *} \\
0.40^{* * *}\end{array}$ & $\begin{array}{l}-0.344^{* * * *} \\
0.41^{* *}\end{array}$ & $\begin{array}{l}0.67 * 7 * 7 * \\
-0.37 * *\end{array}$ & $\begin{array}{l}0.77^{* * * *} \\
-0.32 * * *\end{array}$ & $\begin{array}{c}1 \\
-0.30 * * *\end{array}$ \\
\hline 16. SWLS at T2 & 869 & 5.32 & 1.16 & 0.06 & 0.03 & $0.30 * * *$ & $-0.45 * * *$ & $0.35 * * *$ & $0.24 * * *$ & $-0.31 * * *$ & $0.35^{* * *}$ & $0.38 * * *$ & $0.45 * * *$ & $-0.31 * * *$ & $-0.38 * * *$ & $-0.38 * * *$ \\
\hline 17. QoL at T0 & 867 & 4.25 & 0.69 & -0.04 & 0.05 & $0.33 * * *$ & $-0.36 * * *$ & $0.18 * * *$ & $0.10^{* *}$ & $-0.34 * * * *$ & $0.57^{* * * *}$ & $0.46 * * *$ & $0.49 * * *$ & $-0.31 * * *$ & $-0.26 * * *$ & $-0.24 * * *$ \\
\hline $\begin{array}{l}\text { 18. QoL at T1 } \\
\text { 19. Oo at T2 }\end{array}$ & $\begin{array}{l}870 \\
870\end{array}$ & $\begin{array}{l}4.23 \\
4.22\end{array}$ & $\begin{array}{l}0.71 \\
0.71\end{array}$ & $\begin{array}{l}0.01 \\
0.01\end{array}$ & $\begin{array}{l}0.04 \\
0.06\end{array}$ & $\begin{array}{l}0.31^{* * *} \\
0.32 * *\end{array}$ & $\begin{array}{l}-0.37 * * * \\
-0.38 * * *\end{array}$ & $\begin{array}{l}0.23 * * * \\
0.25 * * *\end{array}$ & $\begin{array}{l}0.13^{* * *} \\
0.15^{* * * *}\end{array}$ & $\begin{array}{l}-0.36 * * * \\
-0.33 * * *\end{array}$ & $\begin{array}{l}0.46 * * * \\
0.45 * * *\end{array}$ & $0.59 * * *$ & 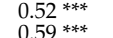 & $\begin{array}{l}-0.25 * * * \\
-0.26 * *\end{array}$ & $\begin{array}{l}-0.37 * * * \\
-0.33 * *\end{array}$ & $-0.30^{* * *}$ \\
\hline $\begin{array}{l}\text { 19. OOL at 12 } 2 \\
\text { 20. JOBSAT at T0 }\end{array}$ & $\begin{array}{l}870 \\
870\end{array}$ & 3.16 & $\begin{array}{l}. .11 \\
0.47\end{array}$ & $\begin{array}{l}0.01 \\
0.02\end{array}$ & $\begin{array}{l}0.06 \\
0.05\end{array}$ & $\begin{array}{l}0.32 * * * \\
0.18 * * *\end{array}$ & $\begin{array}{l}-0.38 * * * 4 \\
-0.26 * *\end{array}$ & $\begin{array}{l}0.25 * * * \\
0.11 * *\end{array}$ & $\begin{array}{l}0.15^{* * * 4} \\
0.06\end{array}$ & $\begin{array}{l}-0.33 * * * 4 \\
-0.21 * *\end{array}$ & $\begin{array}{l}0.45^{* * *} \\
0.27 * *\end{array}$ & $\begin{array}{l}0.48 * * * \\
0.25 * *\end{array}$ & $\begin{array}{l}0.59 * * * \\
28 * * *\end{array}$ & $\begin{array}{l}-0.26 * * * \\
-0.48 * *\end{array}$ & $\begin{array}{l}-0.33 * * * \\
-0.33 * *\end{array}$ & $\begin{array}{l}-0.35 * * * \\
-0.32 * *\end{array}$ \\
\hline 21. JOBSAT at T1 & 839 & 3.15 & 0.47 & 0.03 & 0.03 & $0.17^{* * *}$ & $-0.26 * * *$ & $0.12 * *$ & 0.09 ** & $\begin{array}{l}-0.21 * * * \\
-0.23 *\end{array}$ & $0.24 * * *$ & $0.26 * * *$ & $0.27 * * *$ & $\begin{array}{l}-0.48 * * * \\
-0.32 *\end{array}$ & $\begin{array}{l}-0.33 * * * \\
-0.44 * *\end{array}$ & $-0.34 * * *$ \\
\hline 22. JOBSAT at T2 & 831 & 3.15 & 0.49 & $0.08^{*}$ & $0.08^{*}$ & $0.10^{* *}$ & $-0.24 * * * *$ & $0.12 * *$ & $0.08 *$ & $-0.19 * * *$ & $0.20 * * *$ & $0.19 * * *$ & $0.29 * * *$ & $-0.31 * * *$ & $.37 * * *$ & $-0.50 * * *$ \\
\hline 23. Empoyability at T0 & 870 & 2.21 & 0.81 & $-0.31^{* * * *}$ & 0.01 & 0.03 & $-0.16^{* * * *}$ & $0.15 * * *$ & $0.11^{* *}$ & $-0.14 * * *$ & $0.10^{* *}$ & $0.09 * *$ & $0.10^{* *}$ & $-0.12 * * *$ & $-0.12 * *$ & $-0.08 *$ \\
\hline 24. Empoyability at T1 & 839 & 2.19 & 0.83 & $-0.34 * * * *$ & -0.02 & 0.03 & $-0.18 * * *$ & $0.20 * * *$ & $0.08^{*}$ & $-0.17 * * *$ & $0.14 * * *$ & $0.13 * * *$ & $0.12^{* * *}$ & $-0.10^{* *}$ & $-0.10^{* *}$ & -0.05 \\
\hline 25. Empoyability at $\mathrm{T} 2$ & $\begin{array}{l}830 \\
869\end{array}$ & $\begin{array}{l}2.20 \\
2.33\end{array}$ & 0.82 & $\begin{array}{l}-0.35 * * * * \\
-0.12 * * *\end{array}$ & $\begin{array}{r}0.01 \\
-0.08 *\end{array}$ & 0.06 & $\begin{array}{l}-0.16 * * * \\
-019 * *\end{array}$ & $0.18^{* * *}$ & $0.12 * * *$ & $-0.16 * * *$ & $0.08 *$ & 0.07 & $0.09 * * *$ & $-0.10^{* *}$ & $-0.11 * * *$ & $-0.09 *$ \\
\hline $\begin{array}{l}\text { 26. career prospects at T0 } \\
\text { 27. career prospects at }\end{array}$ & $\begin{array}{l}869 \\
834\end{array}-1$ & $\begin{array}{l}2.33 \\
2.32\end{array}$ & $\begin{array}{l}0.18 \\
0.79\end{array}$ & $\begin{array}{l}-0.12 \\
-0.09 * *\end{array}$ & $\begin{array}{l}-0.08 \\
-0.05\end{array}$ & 0.04 & $-0.17 * * *$ & $0.12 * * *$ & 0.07 ** & $\begin{array}{l}-0.13 * * \\
-0.11 * *\end{array}$ & $\begin{array}{l}0.20^{* * * *} \\
0.16^{* * *}\end{array}$ & $\begin{array}{l}0.18 \text { *1***** } \\
0.16^{* * *}\end{array}$ & $0.15 * * *$ & $\begin{array}{l}-0.22 \\
-0.13 * * *\end{array}$ & $\begin{array}{l}-0.14 * 2 * * * \\
-0.22 *\end{array}$ & $\begin{array}{l}-0.14 \\
-0.15 * * *\end{array}$ \\
\hline \multirow[t]{2}{*}{ 28. career prospects at T2 } & 821 & 2.29 & 0.77 & $-0.11^{* *}$ & -0.07 & 0.03 & $-0.15 * * *$ & $0.17^{* * *}$ & $0.10^{* *}$ & -0.05 & $0.13^{* * *}$ & $0.12 * * *$ & $0.20^{* * *}$ & $-0.14 * * *$ & $-0.15 * * *$ & $-0.19^{* * *}$ \\
\hline & & 14 & 15 & 16 & 17 & 18 & 19 & 20 & 21 & 22 & 23 & 24 & 25 & 26 & 27 & 28 \\
\hline
\end{tabular}

\begin{tabular}{|c|c|c|c|c|c|c|c|c|c|c|c|c|c|c|c|c|}
\hline & & 14 & 15 & 16 & 17 & 18 & 19 & 20 & 21 & 22 & 23 & 24 & 25 & 26 & 27 & 28 \\
\hline 14. SWLS at T0 & & 1 & & & & & & & & & & & & & & \\
\hline $\begin{array}{l}\text { 15. SWLS at T1 } \\
\text { 16. SWLS at T2 }\end{array}$ & & $\begin{array}{l}0.77^{* * *} \\
0.72^{* * *}\end{array}$ & ${ }^{1} .77^{* * *}$ & & & & & & & & & & & & & \\
\hline 17. QoL at T0 & & $0.60^{* * *}$ & $0.51 * * *$ & $0.52^{* * *}$ & & & & & & & & & & & & \\
\hline 18. QoL at T1 & & $0.55^{* * * *}$ & $0.61 * * *$ & $0.56 * * *$ & $0.59 * * *$ & 1 & & & & & & & & & & \\
\hline $\begin{array}{l}\text { 19. JOBSAT at TO } \\
\text { 20. JOB }\end{array}$ & & $\begin{array}{l}0.53^{* * *} \\
0.43^{* * *}\end{array}$ & $\begin{array}{l}0.58^{* * *} \\
0.36^{* * *}\end{array}$ & $\begin{array}{l}0.66^{* * * *} \\
0.32^{* * *}\end{array}$ & $\begin{array}{l}0.59^{* * * *} \\
0.35^{* * *}\end{array}$ & $\begin{array}{l}0.66^{* * * *} \\
0.28^{* * *}\end{array}$ & $0.28^{* * *}$ & 1 & & & & & & & & \\
\hline 21. JOBSAT at T1 & & $0.35^{* * * *} 0$ & $0.43^{* * * *}$ & $0.36^{* * *}$ & $0.31^{* * *} 0$ & $0.36^{* * *}$ & $0.34^{* * *}$ & $0.61^{* * *}$ & $1_{2 * * *}$ & & & & & & & \\
\hline $\begin{array}{l}\text { 22. J JBSAT at T2 } \\
\text { 23. Empoyability at TO }\end{array}$ & & $0.16^{* * *}$ & $0.12^{* * *}$ & $0.16^{* * *}$ & $0.27^{* * * *}$ & $\begin{array}{l}0.33^{* * * *} \\
0.12^{* *}\end{array}$ & $\begin{array}{l}0.355^{* * *} \\
0.11^{* *}\end{array}$ & $\begin{array}{l}0.53^{* * * *} \\
0.14 * * *\end{array}$ & $0.1^{* * * *}$ & $1^{1} 4_{* * *}$ & & & & & & \\
\hline 24. Empoyability at T1 & & $0.16^{* * *}$ & $0.15^{* * *}$ & $0.16^{* * *}$ & $0.18^{* * *}$ & $0.16^{* * *}$ & $0.13^{* * *}$ & $0.17 * *$ & $0.17^{* * *}$ & $0.13^{* * *}$ & $0.69 * * *$ & 1 & & & & \\
\hline 25. Empoyability at T2 & & $0.18^{* * *}$ & $0.14^{* * *}$ & $0.19^{* * *}$ & $0.16^{* * *}$ & $0.14 * * *$ & $0.11^{* *}$ & $0.14 * * *$ & $0.16^{* * *}$ & $0.14 * * *$ & $0.68 * * *$ & $0.70^{* * *}$ & 1 & & & \\
\hline $\begin{array}{l}\text { 26. career prospects at T0 } \\
\text { 27 career prospects at } \mathrm{T} 1\end{array}$ & & $\begin{array}{l}0.32 * * * * \\
0.22 * * *\end{array}$ & $\begin{array}{l}0.27^{* * *} \\
0.31^{* * *}\end{array}$ & $0.23^{* * *}$ & $\begin{array}{l}0.18^{* * *} \\
0.11^{* *}\end{array}$ & $\begin{array}{l}0.19^{* * *} \\
0.18^{* * *}\end{array}$ & $\begin{array}{l}0.16^{* * *} \\
0.13 * *\end{array}$ & $\begin{array}{l}0.40^{* * *} \\
0.30^{* * *}\end{array}$ & $\begin{array}{l}0.30^{* * *} \\
0.4 * *\end{array}$ & $\begin{array}{l}0.23 * * * \\
0.33 * * *\end{array}$ & $\begin{array}{l}0.19^{* * *} \\
0.18^{* * *}\end{array}$ & $\begin{array}{l}0.19^{* * *} \\
0.17 * *\end{array}$ & $0.21^{* * * * *} 0$ & $\begin{array}{l}1 \\
0.58 * * *\end{array}$ & & \\
\hline 28 career prospects at $\mathrm{T} 2$ & & $0.18^{* * *}$ & $0.22 * * *$ & $0.23^{* * *}$ & $0.11^{* *}$ & $0.12^{* *}$ & $0.15^{* * *}$ & $0.26^{* * *}$ & $0.31^{* * *}$ & $0.40 * * *$ & $0.22 * * *$ & $0.22 * * *$ & $0.25^{* * *}$ & $0.56^{* * *}$ & $0.61 * * *$ & 1 \\
\hline 29. Positive work events & 47 & & & -0.03 & 0.02 & 0.00 & -0.02 & 0.06 & 0.00 & 0.01 & -0.05 & 0.02 & 0.02 & $0.10^{* *}$ & 0.01 & 0.05 \\
\hline 30. Postltive nonwork events & 55 & & & $-0.19+14$ & -0.03 & 0.03 & -0.06 & 0.01 & -0.04 & $-0.07 * *$ & $0.090^{\circ}$ & $0.12 * * *$ & $0.111^{* * * *}$ & $-0.05 *$ & $\begin{array}{l}-0.02 * \\
* * * *\end{array}$ & $-0.05 *$ \\
\hline $\begin{array}{l}\text { 31. Negative work events } \\
\text { 32. Negative nonwork events }\end{array}$ & $\begin{array}{l}55 \\
115\end{array}$ & & & $0.02 *$ & $0.017 * *$ & $\begin{array}{l}-0.01 \\
-0.02\end{array}$ & $0.113 * *$ & $\begin{array}{l}-0.02 \\
-0.07\end{array}$ & -0.07 & 0.1405 & $\begin{array}{l}-0.08 * \\
-0.07 *\end{array}$ & $-0.17 * * *$ & $\begin{array}{l}-0.13 * * * \\
-0.12 * *\end{array}$ & 0.1600 & $0.17 \times 4$ & $0.19+02$ \\
\hline \multirow[t]{2}{*}{ 33. No events reported } & 435 & & & $0.09 *$ & $-0.11 * *$ & 0.00 & $\begin{array}{l}.10 .09 * \\
-0.09\end{array}$ & 0.02 & $0.07^{*}$ & -0.06 & 0.06 & $0.09 *$ & 0.06 & $-0.10^{* *}$ & $-0.10^{* *}$ & $-0.10^{* *}$ \\
\hline & & 14 & 15 & 16 & 17 & 18 & 19 & 20 & 21 & 22 & 23 & 24 & 25 & 26 & 27 & 28 \\
\hline $\begin{array}{l}\text { 29. Positive work events } \\
\text { 30. Positive nonwork events } \\
\text { 31. Negative work events } \\
\text { 33. Negative nonwork events } \\
\text { 33. Nonts reported }\end{array}$ & & $\begin{array}{c}0.01 \\
0.07 \\
-0.14 * * * \\
-0.04 \\
0.04\end{array}$ & $\begin{array}{c}0.04 \\
0.12^{* *} \\
-0.19^{* * * *} \\
-0.077^{*} \\
0.05\end{array}$ & $\begin{array}{c}0.05 \\
0.07 \\
-0.16^{* * *} \\
-0.07 * \\
0.06\end{array}$ & $\begin{array}{l}-0.04 \\
0.10^{* *} \\
-0.14 * * * \\
0.02 \\
0.01\end{array}$ & $\begin{array}{c}0.078^{*} \\
0.133^{* * *} \\
-0.18^{* * *} \\
-0.09 * \\
0.03\end{array}$ & $\begin{array}{c}0.04 \\
0.124^{* *} \\
-0.14^{* * *} \\
-0.06 \\
0.01\end{array}$ & $\begin{array}{c}-0.06 \\
0.02 \\
-0.16^{* * *} \\
-0.01 \\
0.11^{* *}\end{array}$ & $\begin{array}{l}0.10^{* *} \\
0.01 \\
-0.21 * * * \\
0.04 \\
0.02\end{array}$ & $\begin{array}{l}0.06 \\
0.02 \\
-0.15 * * * \\
0.01 \\
0.03\end{array}$ & $\begin{array}{l}0.09 * \\
0.06 \\
-0.06 \\
-0.07 \\
-0.01\end{array}$ & $\begin{array}{c}0.07 * \\
0.06 \\
-0.09 * \\
-0.07 \\
0.01\end{array}$ & $\begin{array}{c}0.08^{*} \\
0.06 \\
-0.10 * * \\
-0.07 \\
0.02\end{array}$ & $\begin{array}{c}-0.01 \\
0.03 \\
-0.15^{* * *} \\
-0.06 \\
0.10^{* *}\end{array}$ & $\begin{array}{c}0.10^{* *} \\
0.04 \\
-0.13^{* * *} \\
-0.09 * \\
0.05\end{array}$ & $\begin{array}{c}0.09 * \\
0.02 \\
-0.08^{*} \\
-0.08^{*} \\
0.04\end{array}$ \\
\hline
\end{tabular}

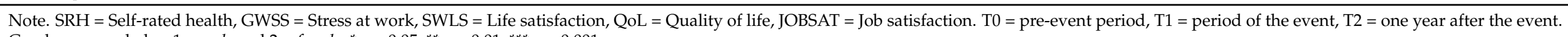
Gender was coded as $1=$ male and $2=$ female. ${ }^{*} p<0.05,{ }^{* *} p<0.01,{ }^{* * *} p<0.001$. 
Table 2. Mean-Level Changes in health, happiness and productivity by type of life events.

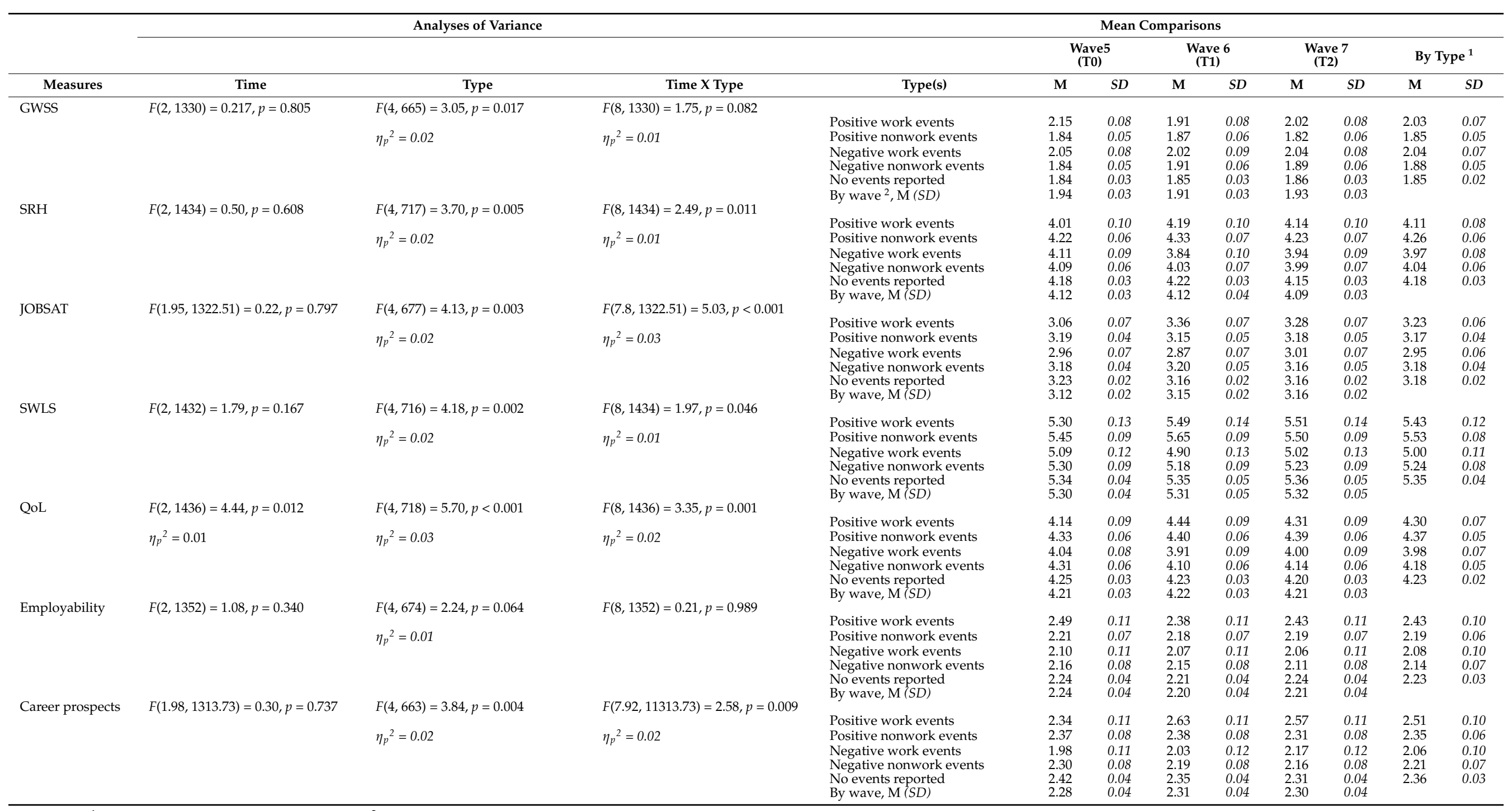

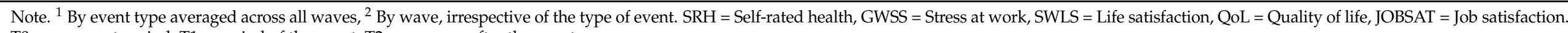

$\mathrm{T} 0=$ pre-event period, $\mathrm{T} 1=$ period of the event, $\mathrm{T} 2=$ one year after the event. 


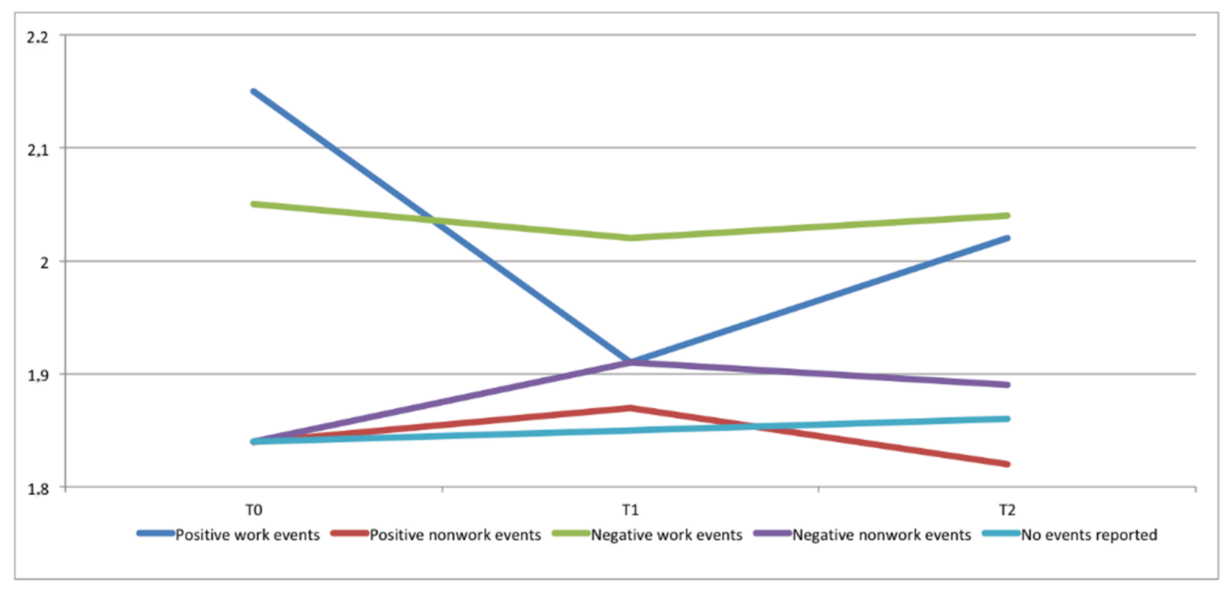

(a)

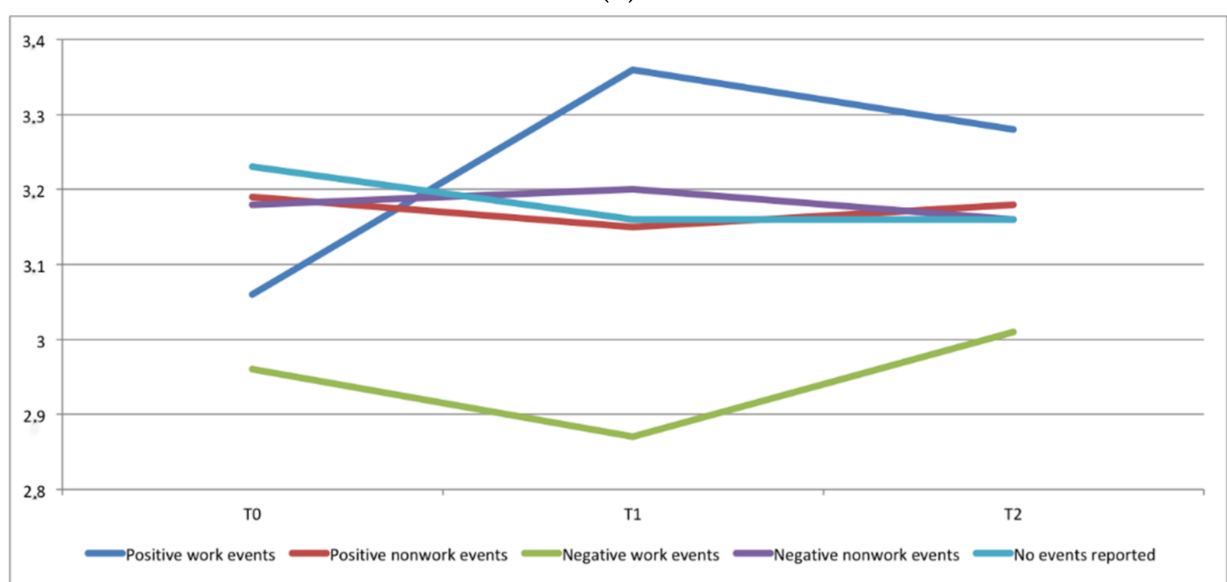

(c)

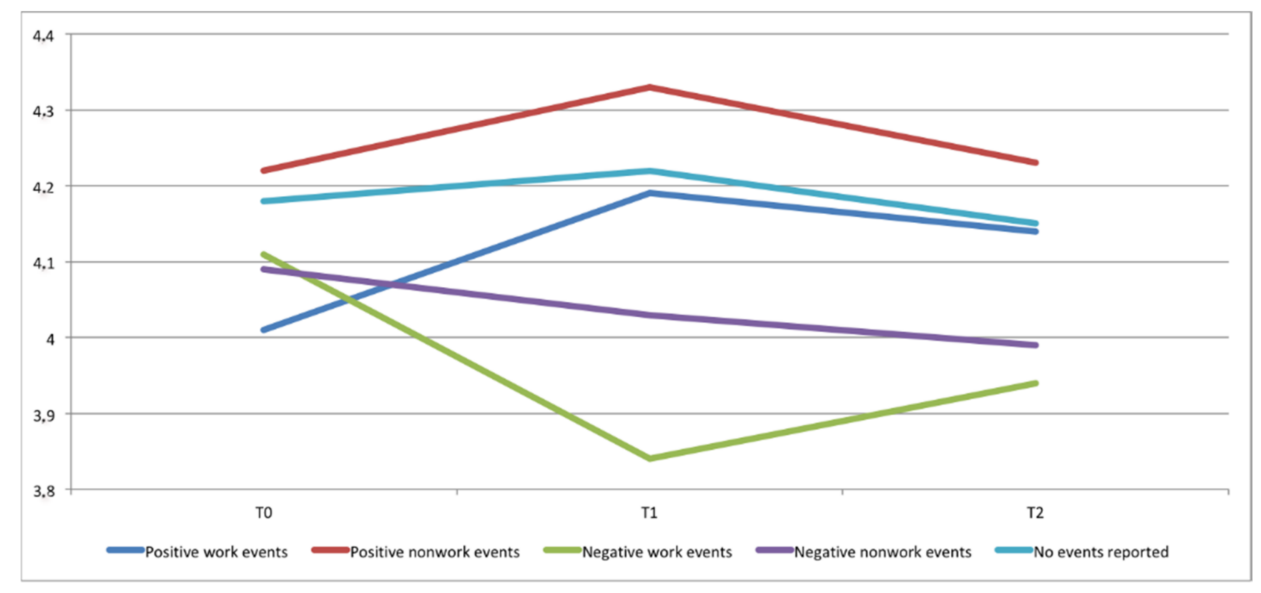

(b)

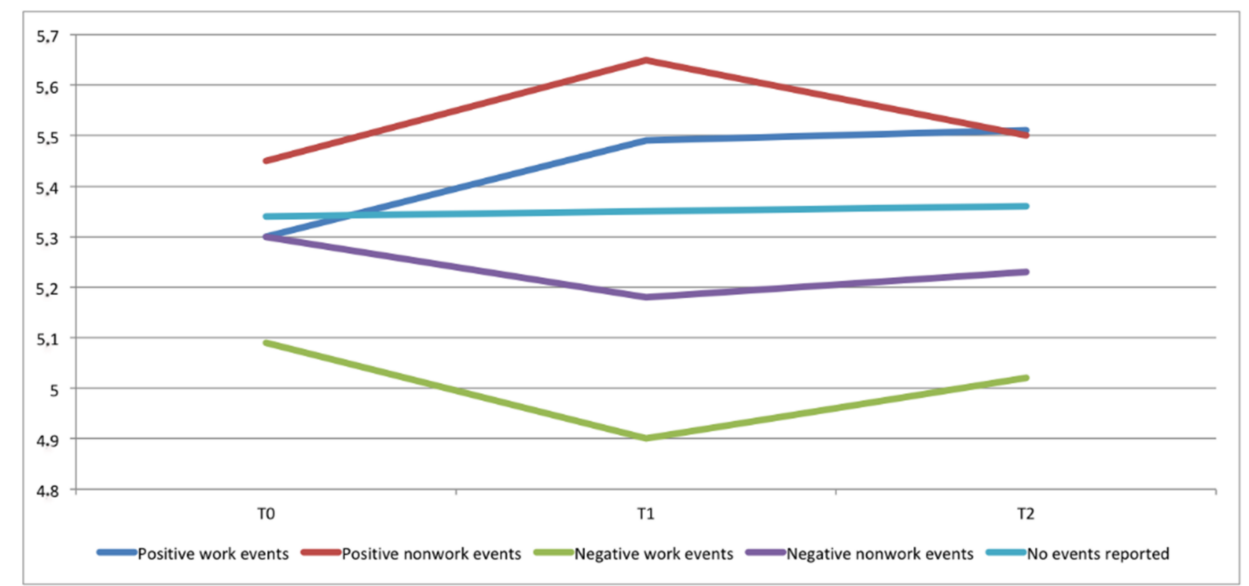

(d)

Figure 1. Cont. 


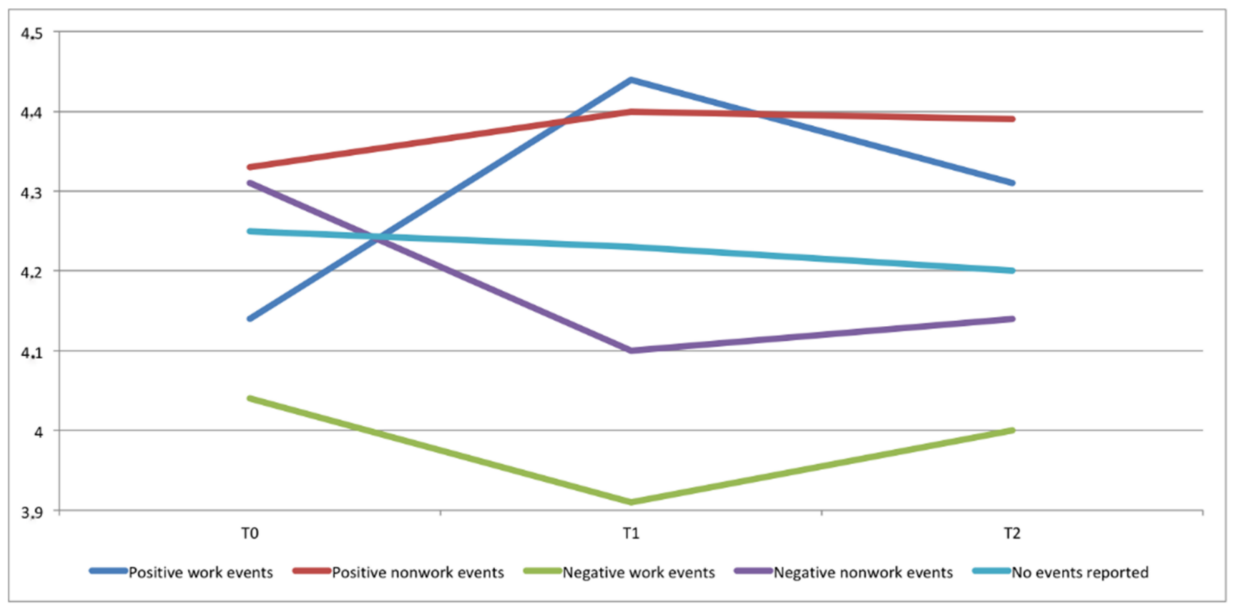

(e)

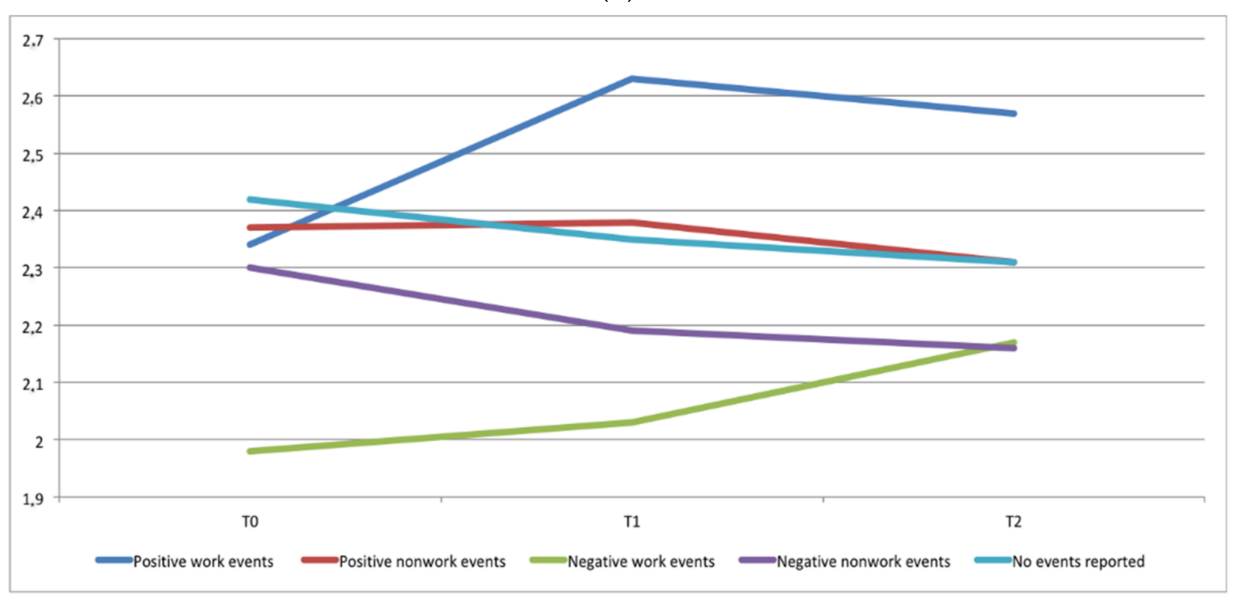

(g)

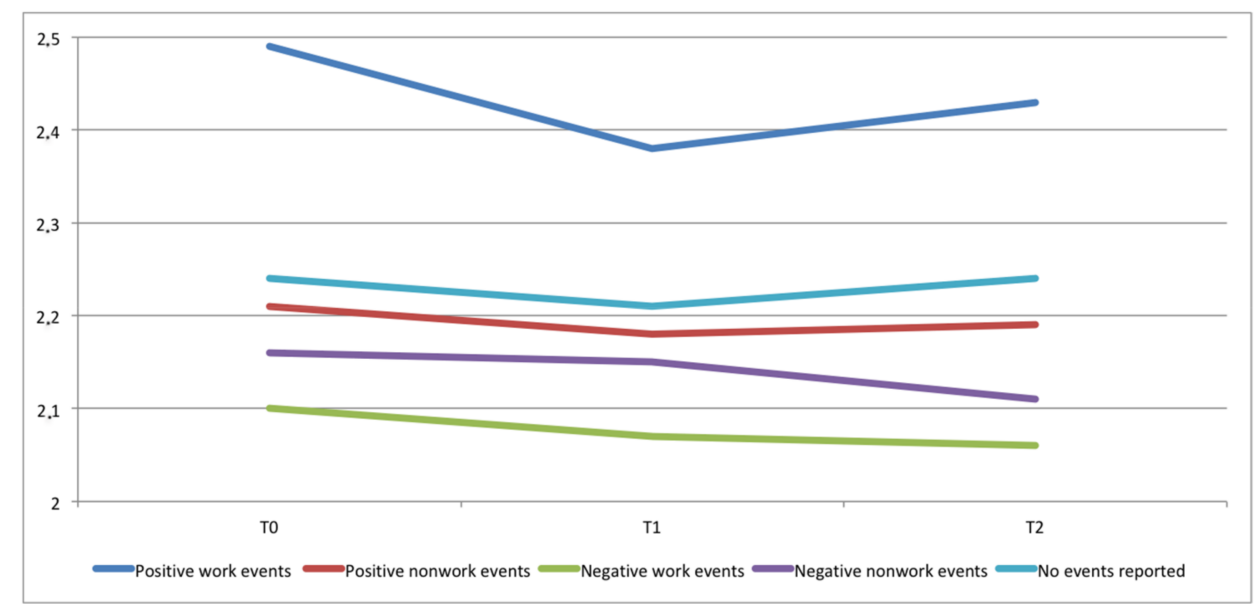

(f)

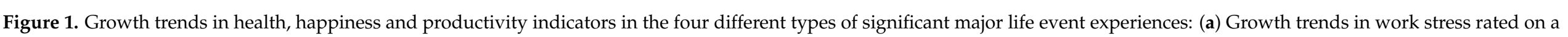

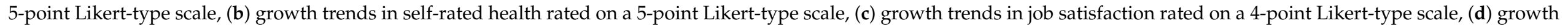

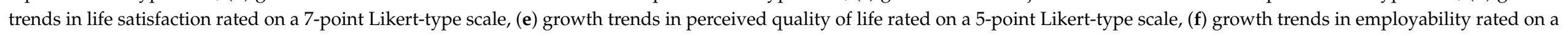
4-point Likert-type scale, and (g) growth trends in career prospects rated on a 4-point Likert-type scale. 
Results indicated a nonsignificant mean-level change in SRH between T0 and T2. However, the moderation analysis indicated a significant interaction effect between the time and type of event. The interaction effect showed a significant quadratic effect, $F(4,717)=3.05$, $p=0.017$. We found also a main effect of the type of event: Individuals reporting positive nonwork events had a higher score on SRH than those reporting negative work events $(d=0.30, p=0.024)$ and negative nonwork events $(d=0.22, p=0.049)$. As illustrated in Figure $1 b$, positive work events had positive effects on $\mathrm{SRH}$, whereas negative work events had negative effects on SRH. These effects tended to disappear in the long term.

\subsection{Effect of Type of Event on Happiness}

Job satisfaction (indicative of work-related happiness), life satisfaction (indicative of overall life happiness), and QoL (indicative of overall health and happiness) were used as dependent variables in RM ANOVAs.

For job satisfaction, Mauchly's test showed that the assumption of sphericity had been violated; consequently, degrees of freedom were corrected using Greenhouse-Geisser estimates of sphericity. Results indicated a nonsignificant mean-level change in life satisfaction between T0 and T2. However, the moderation analysis indicated a significant interaction effect between the time and type of event. The interaction effect showed significant linear, $F(4,667)=4.39, p=0.002$, and quadratic effects, $F(4,667)=5.91, p<0.001$. We found also a main effect of the type of event: Individuals reporting negative work events scored lower on SWLS than those reporting negative nonwork events $(d=-0.23, p=0.008)$, positive work events $(d=-0.28, p=0.005)$, positive nonwork events $(d=-0.22, p=0.011)$, and individuals who did not report any significant events $(d=-0.23, p=0.001)$. As illustrated in Figure 1c, positive work events had a positive effect on job satisfaction at T1, and this effect remained 1 year later; however, negative work events had a negative effect on job satisfaction, but this effect disappeared 1 year later.

For life satisfaction, the results indicated a nonsignificant mean-level change in life satisfaction between T0 and T2. However, the moderation analysis indicated a significant interaction effect between the time and type of event. The interaction effect showed a significant quadratic effect, $F(4,716)=2.83, p=0.024$. We found also a main effect of the type of event: Individuals reporting negative work events scored lower on SWLS than those reporting positive nonwork events $(d=-0.53, p=0.001)$ and those who did not report any significant events $(d=-0.35, p=0.041)$. As illustrated in Figure $1 d$, positive nonwork events had positive effects on life satisfaction at $\mathrm{T} 1$, but this effect disappeared one year later. Similarly, negative work events had a negative effect on life satisfaction, and this effect disappeared one year later. On the contrary, positive work events had a positive effect on life satisfaction at T1, and this effect remained one year later.

For quality of life, results indicated significant mean-level changes in QoL between T0 and T2. Specifically, there was a slight decrease in QoL from T1 to T2. The moderation analysis indicated a significant interaction effect between the time and type of event. The interaction effect showed both a significant linear, $F(4,718)=2.94, p=0.020$, and quadratic effect, $F(4,718)=3.77, p=0.005$. We found also a main effect of the type of event: Individuals reporting negative work events reported lower level of QoL than the ones reporting positive work events $(d=-0.31, p=0.017)$, positive nonwork events $(d=-0.39$, $p<0.001)$ and those who did not report any significant events $(d=-0.25, p=0.008)$. As illustrated in Figure 1e, positive work events had a positive effect on QoL at T1, and this effect remained one year later, whereas negative nonwork events had a negative effect on QoL at T1, and this effect also remained one year later.

\subsection{Effect of Type of Event on Productivity}

For employability as a dependent variable, results indicated a nonsignificant meanlevel change in life satisfaction between T0 and T2, a marginally significant main effect of the type of event $(p=0.064)$, and a nonsignificant interaction effect between the time and 
type of event. Figure $1 \mathrm{f}$ shows that individuals reporting negative work events had lower levels of perceived employability than those reporting positive work events.

For career prospects, Mauchly's test showed that the assumption of sphericity had been violated; consequently, Greenhouse-Geisser estimates of sphericity was used to correct degrees of freedom. Results indicated a nonsignificant mean-level change in career prospects between $\mathrm{T} 0$ and $\mathrm{T} 2$. However, the moderation analysis indicated a significant interaction effect between the time and type of event. The interaction effect showed a significant linear effect, $F(4,663)=3.67, p=0.006$. We found also a main effect of the type of event: Individuals reporting negative work events tended to perceive lower career prospects than those reporting positive work events $(d=-0.45, p=0.010)$ and those who did not report any significant events $(d=-0.30, p=0.040)$. As illustrated in Figure $1 \mathrm{~g}$, positive work events had a positive effect on perceived career prospects at $\mathrm{T} 1$, and this effect remained 1 year later.

\section{Discussion}

The present study aimed to examine the immediate and long-lasting effects of various types of significant life events on health, happiness, and productivity using the sustainable career framework. Overall, results indicated that significant life events, especially those falling into the work domain, are important to consider when studying career sustainability, and we also found some evidence for spillover effects from work to life. Moreover, experiencing positive work events seems to boost career sustainability, and these effects are stronger than the negative effect of negative work or nonwork events on health, happiness, and productivity.

\subsection{The Role of Positive Work Events in Fostering Career Sustainability}

Hypothesis 1 was only partially confirmed. Although positive work events fostered career sustainability, negative work events did not hinder it. Indeed, experiencing positive work events had an immediate and long-lasting positive effect on work-related happiness and career prospects. It also had positive effects on work stress (which decreased) but only in the short run. Our study highlights for the first time the long-lasting benefits of positive work events on job satisfaction and the importance of considering positive work events when studying career prospects. Experiencing positive events at work increased employees' level of satisfaction with their work, enhanced their perception of their future career in the short and long run, and decreased their work stress momentarily. These results fall in line with the sustainable career theory, which points out the importance of considering an event and its interaction with time to predict different work-related outcomes [9].

Although positive work events seem to foster career sustainability, the effects of negative work events were only marginal. Indeed, results indicated that negative work events had an immediate but small effect, especially on job satisfaction, which is in line with stressor-strain models [74]. More surprising was their positive effects on career prospects in the long run. One explanation could be that people tend to proactively cope with negative events in the long run. In other words, even though individuals experience negative events at the workplace that negatively impact their job satisfaction right after they occur, they may activate their resources to counteract these negative effects in order to finally return to their pre-event level of job satisfaction and even improve their view of career prospects.

Although negative work events did not hinder career sustainability, participants who reported these negative events also reported poorer outcomes (in terms of health, happiness, and perceived career prospects) across all waves than those who faced positive work and/or nonwork events. This suggests that individuals reporting negative experiences at work could face in parallel other vulnerabilities hindering their career sustainability.

Hypothesis 2 was not confirmed. Indeed, there was scarce evidence that nonwork events would hinder or foster career sustainability. However, some interesting trends were observed. For example, negative nonwork events had small immediate and long-lasting effects on career prospects. Our findings suggest that experiencing negative events outside 
of the workplace may negatively impact the way individuals perceive their career prospects, whereas the opposite effect was observed for negative work events. Our findings suggest that individuals had the resources to counteract the negative effects of negative work events and could even use them to boost their career prospects. However, they could not mobilize enough resources to cope with the negative effects of negative nonwork events on career prospects. One explanation of this result could be that some negative effects (and their impacts on careers) might be predictable in the work domain and that people can activate available resources (i.e., personal and organizational means) to cope with them. However, when the negative event happens outside of the workplace, its impact on work might not be so easily counteracted because people may not have readily available external resources and/or organizations might not have the necessary resources to support employees facing those events.

In sum, our findings suggest first that positive work events enhance career sustainability. Second, individuals reporting negative work events seemed to already be in a more precarious situation, which might explain why negative work events did not worsen it.

Finally, Hypothesis 3 was confirmed. Indeed, although it is not clear to what extent events occurring outside of the work domain may affect career sustainability, nonwork events were found to have a certain effect on general health and well-being outcomes. In other words, neither positive nor negative nonwork events directly impacted workrelated outcomes.

\subsection{Evidence for Work-Life Spillover Effects}

The current study yielded some evidence for work-to-life spillover effects. Indeed, positive work events had both an immediate and long-lasting impact on life satisfaction and QoL. They also had an immediate effect on SRH. These results confirm the so-called role enhancement hypothesis or positive spillover mechanism, which postulates that positive experiences at work may also improve one's functioning in the other life domains [75]. In addition, this study pointed out a negative effect of negative work events on SRH and life satisfaction and a marginally significant effect on QoL, but only in the short run for all of them. Along with the small effect of nonwork events on work-related indicators, these findings tend to confirm the observation made by Geurts and Demerouti [25] about the higher prevalence of work influencing home rather than home influencing work. Moreover, our results also corroborate their findings about employees' tendency to evaluate the impact of nonwork domain experiences on working life as positive rather than negative.

To sum up, positive work events seem to play an important role in increasing workrelated well-being and overall health and happiness. In contrast, the negative effects of negative work events on work-related and overall health and well-being appear to be short lived, reaching their baseline one year after. These findings are consistent with previous research in the SWB literature and especially with adaptation theory $[6,20]$. Indeed, Luhmann and colleagues [6] stressed that a negative work event, such as unemployment, had a strong negative effect on life satisfaction at the time of the event, but the pre-event life satisfaction level was reached again slowly after years. When facing adverse experiences, individuals may thus activate personal, social, or institutional resources to counteract these detrimental effects and re-establish their well-being. However, results should be interpreted carefully, as different characteristics of the event, such as its foreseeability, length, or frequency, should be taken into account for a finer understanding of these processes. For example, unemployment may have more detrimental, persistent negative effects on health and well-being when the event is more unpredictable, involuntary, and long lasting compared to the opposite case. Whereas Luhmann and colleagues [6] found evidence for the adaptation pattern, it is all the more necessary that Mousteri and colleagues [53] found evidence for the scarring effect of unemployment on life satisfaction and QoL across various countries. These contrasting results highlight the importance for future studies to thoroughly analyze the characteristics of each event and the way they interact with personal, social, and institutional resources in predicting health and well-being. 


\subsection{Perceived Employability: More a Resource Than an Outcome}

Even though De Vos et colleagues [9] stressed in the sustainable career framework the importance of accounting for employability as an indicator of productivity to study career sustainability, our findings did not show any significant direct effects regarding perceived employability, so its role and place in the sustainable career framework should be clarified. Employability denotes one's standing (actual performance along with opportunities, desirability to employers, etc.) in the labor market and can be assessed objectively or subjectively. Although objective employability clearly reflects individuals' labor market outcomes and performance (e.g., reflected in one's skills and employment history), subjective or perceived employability (e.g., a belief that one could find a similar job) might also act as a self-regulatory resource, similar to career self-efficacy or adaptability [76], or as a psychosocial resource [77]. Therefore, two different indicators could be distinguished: the actual performance, which is a workplace outcome, and the confidence in finding a similar job, which has a higher chance of being a mediator of the relation between life events and performance than a direct outcome. Although De Vos and colleagues [9] recognized perceived employability to be more of a personal resource, future studies examining employability within the career sustainability framework could assess objective employability as an indicator of productivity, whereas perceived employability might be used as a resource by the person, which might interact with the time and the events to predict health, happiness, and productivity.

\subsection{Theoretical and Organizational Implications}

By linking this study's variables to the different dimensions and indicators of the sustainable career framework, we advanced empirical knowledge on how events interact with time to predict health, happiness and productivity. Our findings are in good agreement with the chosen framework given that they showed the relevance of adopting a broad and integrative perspective to understand career sustainability. Indeed, using multiple indicators, including both positive and negative, work and nonwork events, and distinguishing between immediate and long-term effects allowed us to conclude that positive work events contribute to long-term career sustainability. Beyond the occurrence of an event, its characteristics should also be taken into account to better understand (dis)continuity in career experiences. Moreover, this study underscores not only the central role of work events in career sustainability, but also the importance of having different indicators of career sustainability and choosing the most relevant ones to understand sustainable career processes.

Our findings have also some implications for organizations and managerial practices. Indeed, in work and organizational psychology, most practices tend to focus on a narrow scope of antecedents (e.g., work-related events or other work/organizational factors), whereas our findings show that multiple life domains should be considered in order to properly understand employees' long-term outcomes. This implies the importance of adopting a systemic approach when planning organizational/managerial interventions and/or trying to understand people's diverse reactions to various events. Moreover, our findings pointed out the key role of employees' positive experiences toward their career sustainability. Based on this result, organizations, especially managers, should be encouraged to provide positive moments for their employees at work. For example, they might recognize even the smallest personal successes and create a moment at the end of the day where employees can share their positive daily experiences and/or increase group cohesion by organizing group activities. Such microinterventions may provide an opportunity for employees to experience positive work events, which may in turn increase their work-related and overall health and well-being, as well as their confidence and optimism about their career advancement and opportunities. In parallel, organizations should continue to do what is necessary to help employees cope with not only negative experiences in the workplace but also nonwork events that may potentially have an impact on employees' work-related health, happiness, and productivity. Finally, through tailor- 
made interventions for vulnerable persons [78], organizations should also pay particular attention to workers who already have a lower level of health, happiness, and productivity, as well as to those who struggle to find a decent work-life balance and a sustainable career.

\subsection{Limitation and Future Directions}

The present study has some limitations that must be taken into account. First, groups of employees who experienced different types of events were rather modest in size, which limits the power of the comparisons and encumbers the interpretation of the results. We suggest that future studies should test our findings on larger samples. Second, although we aimed to encompass the period spanning from pre- to post-event, we might have overlooked the actual moment of the event. Indeed, the time span between the occurrence of the event and participation in the study could not be controlled for, which may have affected the strength of the observed effects, even though a recent study showed that the rank orders of most of the major life event characteristics over one year were relatively stable [24]. Hence, future studies could adopt a more dynamic approach by using an intensive longitudinal design. Third, we used an open-ended question to assess significant life events, and external raters attributed event valence. It would be relevant to check if participants' attributed valence to events would yield similar results. Finally, other indicators could be used for health, happiness, and, in particular, productivity. We encourage future studies to include more performance-related outcomes and better distinguish between work- and career-related outcomes and resources. Moreover, future research should continue to analyze the interplay between the individual, context, and time while also considering all three indicators of career sustainability. Researchers should also continue to test the interaction between life events and psychological resources (e.g., social support or career adaptability) in predicting health, happiness, and productivity. Finally, further developments of the sustainable careers framework might benefit from a stronger focus on life-work domain interrelationships and the mutual influences between them. It may also be important to distinguish between short- and long-term dynamics and conduct more research on these aspects.

\section{Conclusions}

The current study showed the importance of taking into account multiple indicators of health, happiness, and productivity to better understand how different life events interact with time to predict career sustainability. By adopting an integrative and longitudinal perspective, we pointed out which significant life events played a critical role in career sustainability depending on whether they were negative or positive, and work-related or nonwork related. Significant events, especially significant positive work events played an important role in career sustainability by enhancing individuals' perceived career opportunity and both work-related and overall health and happiness over time. Future research should continue to advance research on career sustainability by focusing on the interrelation between the three dimensions and the three indicators of the career sustainability framework.

Author Contributions: Conceptualization, S.U., I.U., and J.R.; methodology, S.U., L.I.C., and I.U.; validation, L.I.C.; formal analysis, S.U.; writing—original draft preparation, S.U; writing—review and editing, all; supervision, J.R., and J.M. All authors have read and agreed to the published version of the manuscript.

Funding: Authors' contribution benefited from the support of the Swiss National Centre of Competence in Research LIVES-Overcoming vulnerability: Life course perspective, financed by the Swiss National Science Foundation (grant number: 51NF40-185901). This research received no external funding.

Institutional Review Board Statement: Institutional review board approval is not required for nonmedical research with human subjects in Switzerland. This longitudinal panel survey was conducted in compliance with the ethical guidelines and procedures of the University of Lausanne and following 
the Psychologists' Code of Conduct. Therefore, at each wave, participants received first an invitation letter explaining the aims of the study, asking to participate in the survey, and ensuring confidentiality, and informing about their right to stop the survey at any moment.

Informed Consent Statement: Not applicable. Consent to participate was given by accepting invitation letter and to do the survey.

Data Availability Statement: A complete description of the research and collected data are stored in the FORSbase data repository and are available upon request (https: / / forsbase.unil.ch/project/ study-public-overview/16093/0/, accessed on 23 November 2021).

Conflicts of Interest: The authors declare no conflict of interest.

\section{References}

1. Savickas, M.L. Life Design: A Paradigm for Career Intervention in the 21st Century. J. Couns. Dev. 2012, 90, 13-19. [CrossRef]

2. Hall, D.T.; Mirvis, P.H. The new protean career: Psychological success and the path with a heart. In The Career Is Dead: Long Live the Career; Jossey-Bass: San Francisco, CA, USA, 1996; Volume 23, pp. 15-45.

3. Arthur, M.B.; Rousseau, D. The Boundaryless Career; Oxford University Press: New York, NY, USA, 1996.

4. Mainiero, L.A.; Sullivan, S.E. Kaleidoscope careers: An alternate explanation for the "opt-out" revolution. Acad. Manag. Perspect. 2005, 19, 106-123. [CrossRef]

5. Johnston, D.; Lee, W.-S. Extra Status and Extra Stress: Are Promotions Good for Us? ILR Rev. 2013, 66, 32-54. [CrossRef]

6. Luhmann, M.; Hofmann, W.; Eid, M.; Lucas, R.E. Subjective well-being and adaptation to life events: A meta-analysis. J. Personal. Soc. Psychol. 2012, 102, 592-615. [CrossRef]

7. Perrig-Chiello, P.; Hutchison, S.; Knöpfli, B. Vulnerability Following a Critical Life Event: Temporary Crisis or Chronic Distress? A Psychological Controversy, Methodological Considerations, and Empirical Evidence. In Life Course Research and Social Policies: Surveying Human Vulnerabilities across the Life Course; Oris, M., Roberts, C., Joye, D., Stähli, M.E., Eds.; Springer International Publishing: Cham, Switzerland, 2016; Volume 3, pp. 87-111. [CrossRef]

8. Van der Heijden, B.I.J.M.; De Vos, A. Sustainable careers: Introductory chapter. In Handbook of Research on Sustainable Careers; De Vos, A., Van der Heijden, B.I.J.M., Eds.; Edward Elgar Publishing: Cheltenham, UK, 2015; pp. 1-19.

9. De Vos, A.; Van der Heijden, B.I.; Akkermans, J. Sustainable careers: Towards a conceptual model. J. Vocat. Behav. 2020, 117, 103196. [CrossRef]

10. Bessin, M.; Bidart, C.; Grossetti, M. (Eds.) Bifurcations. Les Sciences Sociales Face Aux Ruptures et à L'événement; Éditions La Découverte: Paris, France, 2010.

11. Elder, G.H.; Johnson, M.K.; Crosnoe, R. The Emergence and Development of Life Course Theory. In Handbook of Social Movements across Latin America; Springer: Singapore, 2003; pp. 3-19.

12. Zittoun, T. Dynamics of Life-Course Transitions: A Methodological Reflection. In Dynamic Process Methodology in the Social and Developmental Sciences; Springer: Singapore, 2009; pp. 405-430.

13. Masdonati, J.; Franz, S.; Abessolo, M. Comprendre et accompagner les reconversions professionnelles. In Repères pour l'orientation; Masdonati, J., Massoudi, K., Rossier, J., Eds.; Antipodes: Lausanne, Switzerland, 2019; pp. 79-110.

14. Cohen, S.; Murphy, M.L.; Prather, A.A. Ten Surprising Facts About Stressful Life Events and Disease Risk. Annu. Rev. Psychol. 2019, 70, 577-597. [CrossRef]

15. Schwarzer, R.; Luszczynska, A. Stressful life events. In Handbook of Psychology: Health Psychology; Nezu, A.M., Nezu, C.M., Geller, P.A., Weiner, I.B., Eds.; John Wiley \& Sons Inc.: Hoboken, NJ, USA, 2013; pp. 29-56.

16. Anderson, M.L.; Goodman, J.; Schlossberg, N.K. Counseling Adults in Transition: Linking Schlossberg's Theory with Practice in a Diverse World, 4th ed.; Springer: New York, NY, USA, 2012.

17. Schlossberg, N.K. A Model for Analyzing Human Adaptation to Transition. Couns. Psychol. 1981, 9, 2-18. [CrossRef]

18. Akkermans, J.; Seibert, S.E.; Mol, S.T. Tales of the unexpected: Integrating career shocks in the contemporary careers literature. SA J. Ind. Psychol. 2018, 44,1-10. [CrossRef]

19. Morgeson, F.P.; Mitchell, T.R.; Liu, D. Event System Theory: An Event-Oriented Approach to the Organizational Sciences. Acad. Manag. Rev. 2015, 40, 515-537. [CrossRef]

20. Luhmann, M.; Fassbender, I.; Alcock, M.; Haehner, P. A dimensional taxonomy of perceived characteristics of major life events. J. Personal. Soc. Psychol. 2020. [CrossRef]

21. Lazarus, R.S.; Folkman, S. Stress, Appraisal, and Coping; Springer: New York, NY, USA, 1984.

22. Hobson, C.J.; Delunas, L. National Norms and Life-Event Frequencies for the Revised Social Readjustment Rating Scale. Int. J. Stress Manag. 2001, 8, 299-314. [CrossRef]

23. König, J.; Block, A.; Becker, M.; Fenske, K.; Hertel, J.; Van Der Auwera, S.; Zymara, K.; Völzke, H.; Freyberger, H.J.; Grabe, H.J. Assessment of subjective emotional valence and long-lasting impact of life events: Development and psychometrics of the Stralsund Life Event List (SEL). BMC Psychiatry 2018, 18, 105. [CrossRef] [PubMed]

24. Haehner, P.; Kritzler, S.; Fassbender, I.; Luhmann, M. Stability and change of perceived characteristics of major life events. J. Personal. Soc. Psychol. 2021. [CrossRef] 
25. Geurts, S.A.; Demerouti, E. Work/Non-Work Interface: A Review of Theories and Findings. In The Handbook of Work and Health Psychology; Schabracq, M.J., Winnubst, J.A., Cooper, C.L., Eds.; Wiley: Hoboken, NJ, USA, 2004; pp. $279-312$.

26. Bakker, A.B.; Du, D.; Derks, D. Major life events in family life, work engagement, and performance: A test of the work-home resources model. Int. J. Stress Manag. 2019, 26, 238-249. [CrossRef]

27. Hakanen, J.J.; Bakker, A.B. Born and bred to burn out: A life-course view and reflections on job burnout. J. Occup. Health Psychol. 2017, 22, 354-364. [CrossRef]

28. Van der Heijden, B.; De Vos, A.; Akkermans, J.; Spurk, D.; Semeijn, J.; Van der Velde, M.; Fugate, M. Sustainable careers across the lifespan: Moving the field forward. J. Vocat. Behav. 2020, 117, 103344. [CrossRef]

29. Castro, M.R.; Van der Heijden, B.; Henderson, E.L. Catalysts in career transitions: Academic researchers transitioning into sustainable careers in data science. J. Vocat. Behav. 2020, 122, 103479. [CrossRef]

30. Heslin, P.A.; Keating, L.; Ashford, S.J. How being in learning mode may enable a sustainable career across the lifespan. J. Vocat. Behav. 2020, 117, 103324. [CrossRef]

31. Straub, C.; Vinkenburg, C.; van Kleef, M. Career customization: Putting an organizational practice to facilitate sustainable careers to the test. J. Vocat. Behav. 2020, 117, 103320. [CrossRef]

32. Tordera, N.; Peiró, J.M.; Ayala, Y.; Villajos, E.; Truxillo, D. The lagged influence of organizations' human resources practices on employees' career sustainability: The moderating role of age. J. Vocat. Behav. 2020, 120, 103444. [CrossRef]

33. Bozionelos, N.; Lin, C.-H.; Lee, K.Y. Enhancing the sustainability of employees' careers through training: The roles of career actors' openness and of supervisor support. J. Vocat. Behav. 2019, 117, 103333. [CrossRef]

34. Richardson, J.; McKenna, S. An exploration of career sustainability in and after professional sport. J. Vocat. Behav. 2020, 117, 103314. [CrossRef]

35. Blokker, R.; Akkermans, J.; Tims, M.; Jansen, P.; Khapova, S. Building a sustainable start: The role of career competencies, career success, and career shocks in young professionals' employability. J. Vocat. Behav. 2019, 112, 172-184. [CrossRef]

36. Wordsworth, R.; Nilakant, V. Unexpected change: Career transitions following a significant extra-organizational shock. J. Vocat. Behav. 2021, 127, 103555. [CrossRef]

37. Anders, S.L.; Frazier, P.A.; Shallcross, S.L. Prevalence and effects of life event exposure among undergraduate and community college students. J. Couns. Psychol. 2012, 59, 449-457. [CrossRef]

38. Fritz, C.; Sonnentag, S. Recovery, Health, and Job Performance: Effects of Weekend Experiences. J. Occup. Health Psychol. 2005, 10, 187-199. [CrossRef]

39. Réveillère, C.; Courtois, R. Tracas et événements de vie. Impact sur la santé psychique à la préadolescence [Impact of daily hassles and life events on mental health during preadolescence]. Rev. Francoph. Du Stress Et Du Trauma 2007, 7, $193-204$.

40. Graf, A.S.; Long, D.M.; Patrick, J.H. Successful Aging Across Adulthood: Hassles, Uplifts, and Self-Assessed Health in Daily Context. J. Adult Dev. 2017, 24, 216-225. [CrossRef]

41. Toyama, M.; Sakurai, S. Daily Hassles and Uplifts, and College Students' Health. Jpn. J. Educ. Psychol. 1999, 47, 374-382. [CrossRef]

42. Shimizu, M.; Pelham, B.W. The Unconscious Cost of Good Fortune: Implicit and Explicit Self-Esteem, Positive Life Events, and Health. Health Psychol. 2004, 23, 101-105. [CrossRef] [PubMed]

43. Yoon, H.S.; Sok, S.R. Experiences of violence, burnout and job satisfaction in Korean nurses in the emergency medical centre setting. Int. J. Nurs. Pract. 2016, 22, 596-604. [CrossRef]

44. Bono, J.E.; Glomb, T.M.; Shen, W.; Kim, E.; Koch, A.J. Building Positive Resources: Effects of Positive Events and Positive Reflection on Work Stress and Health. Acad. Manag. J. 2013, 56, 1601-1627. [CrossRef]

45. Diener, E. Subjective well-being: The science of happiness and a proposal for a national index. Am. Psychol. 2000, 55, 34-43. [CrossRef]

46. Suh, E.; Diener, E.; Fujita, F. Events and subjective well-being: Only recent events matter. J. Personal. Soc. Psychol. 1996, 70, 1091-1102. [CrossRef]

47. Anusic, I.; Yap, S.C.Y.; Lucas, R. Testing Set-Point Theory in a Swiss National Sample: Reaction and Adaptation to Major Life Events. Soc. Indic. Res. 2014, 119, 1265-1288. [CrossRef]

48. Lucas, R.E. Adaptation and the Set-Point Model of Subjective Well-Being. Curr. Dir. Psychol. Sci. 2007, 16, 75-79. [CrossRef]

49. Gomez, V.; Krings, F.; Bangerter, A.; Grob, A. The influence of personality and life events on subjective well-being from a life span perspective. J. Res. Personal. 2009, 43, 345-354. [CrossRef]

50. Ilies, R.; Keeney, J.; Scott, B.A. Work-family interpersonal capitalization: Sharing positive work events at home. Organ. Behav. Hum. Decis. Process. 2011, 114, 115-126. [CrossRef]

51. Pocnet, C.; Antonietti, J.-P.; Strippoli, M.-P.F.; Glaus, J.; Preisig, M.; Rossier, J. Individuals' quality of life linked to major life events, perceived social support, and personality traits. Qual. Life Res. 2016, 25, 2897-2908. [CrossRef]

52. Ikeda, T.; Igarashi, A.; Odani, S.; Murakami, M.; Tabuchi, T. Health-Related Quality of Life during COVID-19 Pandemic: Assessing Impacts of Job Loss and Financial Support Programs in Japan. Appl. Res. Qual. Life 2021, 1-17. [CrossRef]

53. Mousteri, V.; Daly, M.; Delaney, L. The scarring effect of unemployment on psychological well-being across Europe. Soc. Sci. Res. 2018, 72, 146-169. [CrossRef] [PubMed]

54. Weiss, H.M. Deconstructing job satisfaction: Separating evaluations, beliefs and affective experiences. Hum. Resour. Manag. Rev. 2002, 12, 173-194. [CrossRef] 
55. Georgellis, Y.; Lange, T.; Tabvuma, V. The impact of life events on job satisfaction. J. Vocat. Behav. 2012, 80, 464-473. [CrossRef]

56. O'Neill, B.S.; Cotton, J.L. Putting the horse before the cart: Understanding the influence of trigger events on justice perceptions and work attitudes. J. Manag. Issues 2017, 29, 343-344.

57. van Harten, J.; de Cuyper, N.; Knies, E.; Forrier, A. Taking the temperature of employability research: A systematic review of interrelationships across and within conceptual strands. Eur. J. Work. Organ. Psychol. 2021, 1-14. [CrossRef]

58. Urbanaviciute, I.; Udayar, S.; Rossier, J. Career adaptability and employee well-being over a two-year period: Investigating cross-lagged effects and their boundary conditions. J. Vocat. Behav. 2019, 111, 74-90. [CrossRef]

59. Erdogan, B.; Bauer, T.N.; Truxillo, D.M.; Mansfield, L.R. Whistle While You Work. J. Manag. 2012, 38, 1038-1083. [CrossRef]

60. Furnée, C.A.; Pfann, G.A.; Groot, W. Health and income: A meta-analysis to explore cross-country, gender and age differences. Eur. J. Public Health 2010, 21, 775-780. [CrossRef] [PubMed]

61. Steel, P.; Schmidt, J.; Shultz, J. Refining the relationship between personality and subjective well-being. Psychol. Bull. 2008, 134, 138-161. [CrossRef]

62. Boyatzis, R.E. Transforming Qualitative Information: Thematic Analysis and Code Development; Sage Publications: London, UK, 1998.

63. Ohly, S.; Schmitt, A. What Makes Us Enthusiastic, Angry, Feeling at Rest or Worried? Development and Validation of an Affective Work Events Taxonomy Using Concept Mapping Methodology. J. Bus. Psychol. 2015, 30, 15-35. [CrossRef]

64. Dohrenwend, B.S.; Krasnoff, L.; Askenasy, A.R.; Dohrenwend, B.P. Exemplification of a method for scaling life events: The Peri Life Events Scale. J. Health Soc. Behav. 1978, 19, 205-229. [CrossRef] [PubMed]

65. McHugh, M.L. Interrater reliability: The kappa statistic. Biochem. Med. 2012, 22, 276-282. [CrossRef]

66. Skevington, S.; Lotfy, M.; O'Connell, K. The World Health Organization's WHOQOL-BREF quality of life assessment: Psychometric properties and results of the international field trial. A Report from the WHOQOL Group. Qual. Life Res. 2004, 13, 299-310. [CrossRef] [PubMed]

67. Diener, E.; Emmons, R.A.; Larsen, R.J.; Griffin, S. The Satisfaction With Life Scale. J. Personal. Assess. 1985, 49, 71-75. [CrossRef] [PubMed]

68. de Bruin, G.P.; Taylor, N. Development of the Sources of Work Stress Inventory. S. Afr. J. Psychol. 2005, 35, 748-765. [CrossRef]

69. Massoudi, K. Le Stress Professionnel: Une Analyse des Vulnérabilités Individuelles et des Facteurs de Risque Environnementaux [Professional Stress: Analysis of Individuals Vulnerabilities and Environmental Risk Factors]; Peter Lang: Bern, Switzerland, 2009.

70. De Cuyper, N.; De Witte, H.; Kinnunen, U.; Nätti, J. The Relationship Between Job Insecurity and Employability and Well-Being Among Finnish Temporary and Permanent Employees. Int. Stud. Manag. Organ. 2010, 40, 57-73. [CrossRef]

71. McCrae, R.R.; Costa, P. A contemplated revision of the NEO Five-Factor Inventory. Personal. Individ. Differ. 2004, 36, 587-596. [CrossRef]

72. Udayar, S.; Urbanaviciute, I.; Morselli, D.; Bollmann, G.; Rossier, J.; Spini, D. The LIVES Daily Hassles Scale and Its Relation to Life Satisfaction. Assessment 2021. [CrossRef]

73. Kim, H.-Y. Statistical notes for clinical researchers: Assessing normal distribution (2) using skewness and kurtosis. Restor. Dent. Endod. 2013, 38, 52-54. [CrossRef]

74. Nakahara, W.; Jex, S.; Horan, K. Employee Stress and Well-Being; Oxford University Press (OUP): Oxford, UK, 2021.

75. Grzywacz, J.G.; Marks, N.F. Reconceptualizing the work-family interface: An ecological perspective on the correlates of positive and negative spillover between work and family. J. Occup. Health Psychol. 2000, 5, 111. [CrossRef]

76. Coetzee, M. A Framework for Assessing and Developing Self-regulatory Positive Psychological Career Attributes for Sustained Employability. In Positive Psychological Intervention Design and Protocols for Multi-Cultural Contexts; Springer: Singapore, 2019; pp. 217-240.

77. Fugate, M.; Kinicki, A.J.; Ashforth, B.E. Employability: A psycho-social construct, its dimensions, and applications. J. Vocat. Behav. 2004, 65, 14-38. [CrossRef]

78. Udayar, S.; Urbanaviciute, I.; Massoudi, K.; Rossier, J. The Role of Personality Profiles in the Longitudinal Relationship between Work-Related Well-Being and Life Satisfaction among Working Adults in Switzerland. Eur. J. Personal. 2020, 34, 77-92. [CrossRef] 